\title{
Novel Electrode Materials for Low-Temperature Solid-Oxide Fuel Cells
}

\author{
Final Progress Report
}

Reporting Period: 24 September 2001 to 23 September 2004

DOE Award Number: DE-FG26-01NT41274

DOE Project Manager: Dr. Lane Wilson

Prepared by

Shaowu Zha, and Meilin Liu

Center for Innovative Fuel Cell and Battery Technologies

School of Materials Science and Engineering

Georgia Institute of Technology

Atlanta, GA 30332-0245

Report Issued: June 2005 


\section{DISCLAIMER}

This report was prepared as an account of work sponsored by an agency of the United States Government. Neither the United States Government nor any agency thereof, nor any of their employees, makes any warranty, express of implied, or assumes any legal liability or responsibility for the accuracy, completeness, or usefulness of any information, apparatus, product, or process disclosed, or represents that its use would not infringe privately owned rights. Reference herein to any specific commercial product, process, or service by trade name, trademark, manufacturer, or otherwise does not necessarily constitute or imply its endorsement, recommendation, or favoring by the United States Government or any agency thereof. The views and opinions of authors expressed herein do not necessarily state or reflect those of the United States Government or any agency thereof. 


\begin{abstract}
Composites electrodes consisting of silver and bismuth vanadates exhibit remarkable catalytic activity for oxygen reduction at $500-550^{\circ} \mathrm{C}$ and greatly reduce the cathodeelectrolyte (doped ceria) resistances of low temperature SOFCs, down to about 0.53 $\Omega \mathrm{cm}^{2}$ at $500^{\circ} \mathrm{C}$ and $0.21 \Omega \mathrm{cm}^{2}$ at $550^{\circ} \mathrm{C}$. The observed power densities of 231, 332, and $443 \mathrm{mWcm}^{-2}$ at 500,525 and $550^{\circ} \mathrm{C}$, respectively, make it possible to operate SOFCs at temperatures about $500^{\circ} \mathrm{C}$. Fuel cell performance depends strongly on the anode microstructure, which is determined by the anode compositions and fabrication conditions. Four types of anodes with two kinds of $\mathrm{NiO}$ and GDC powders were investigated. By carefully adjusting the anode microstructure, the GDC electrolyte/anode interfacial polarization resistances reduced dramatically. The interfacial resistance at 600 ${ }^{\circ} \mathrm{C}$ decreased from $1.61 \Omega \mathrm{cm}^{2}$ for the anodes prepared using commercially available powders to $0.06 \Omega \mathrm{cm}^{2}$ for those prepared using powders derived from a glycine-nitrate process.
\end{abstract}

Although steam reforming or partial oxidation is effective in avoiding carbon deposition of hydrocarbon fuels, it increases the operating cost and reduces the energy efficiency. Anode-supported SOFCs with an electrolyte of $20 \mu \mathrm{m}$-thick Gd-doped ceria (GDC) were fabricated by co-pressing. A catalyst (1\%wt Pt dispersed on porous Gd-doped ceria) for pre-reforming of propane was developed with relatively low steam to carbon (S/C) ratio ( 0.5), coupled with direct utilization of the reformate in low-temperature SOFCs. Propane was converted to smaller molecules during pre-reforming, including $\mathrm{H}_{2}, \mathrm{CH}_{4}$, $\mathrm{CO}$, and $\mathrm{CO}_{2}$. A peak power density of $247 \mathrm{~mW} / \mathrm{cm}^{2}$ was observed when pre-reformed propane was directly fed to an SOFC operated at $600^{\circ} \mathrm{C}$. No carbon deposition was observed in the fuel cell for a continuous operation of 10 hours at $600^{\circ} \mathrm{C}$.

The ability of producing vastly different microstructures and morphologies of the very same material is critical to the fabrication of functionally graded electrodes for solid-state electrochemical devices such as SOFCs and lithium batteries. By carefully adjusting deposition parameters, we have successfully produced oxide nano-powders with the size of $30 \sim 200 \mathrm{~nm}$. Porous films with various microstructures and morphologies are also deposited on several substrates by systematic adjustment of the deposition parameters. Highly porous, excellently bonded and nano-structured electrodes fabricated by combustion CVD exhibit extremely high surface area and remarkable catalytic activities.

Using in situ potential dependent FTIR emission spectroscopy, we have found evidence for two, possibly three distinct di-oxygen species present on the electrode surface. We have successfully identified which surface oxygen species is present under a particular electrical or chemical condition and have been able to deduce the reaction mechanisms. This technique will be used to probe the gas-solid interactions at or near the TPB and on the surfaces of mixed-conducting electrodes in an effort to understand the molecular processes relevant to the intrinsic catalytic activity. Broad spectral features are assigned to the electrochemical-polarization-induced changes in the optical properties of the electrode surface layer. 


\section{TABLE OF CONTENTS}

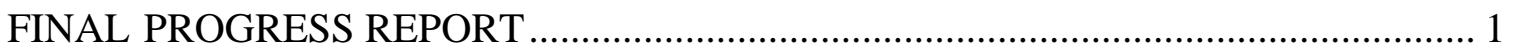

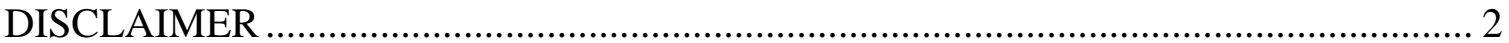

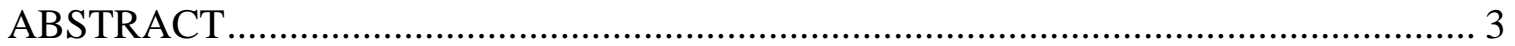

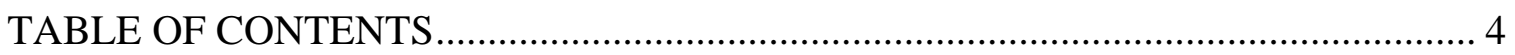

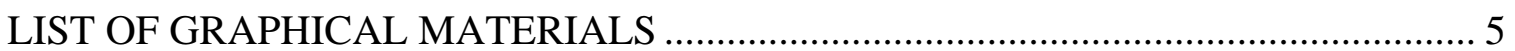

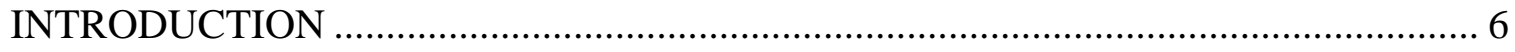

EXECUTIVE SUMMARY................................................................................ 7

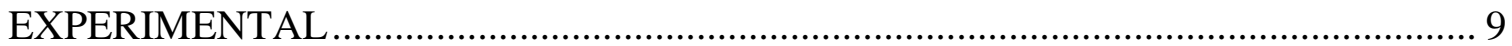

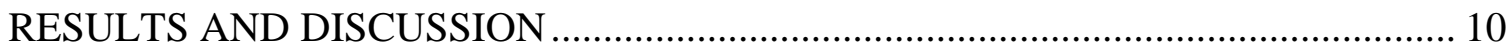

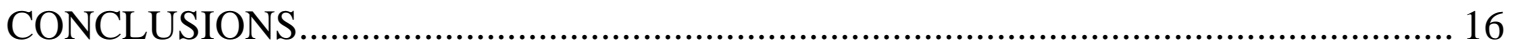

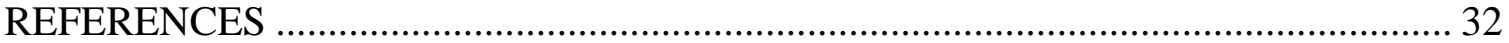




\section{LIST OF GRAPHICAL MATERIALS}

Table 1. Sources of precursor powders and firing temperature ……………………... 18

Figure 1. Comparison of different resistances in the cell ........................................... 18

Figure 2. Cell voltages and power densities of an SOFC ........................................... 19

Figure 3. Impedance spectra of an YDB composite cathode......................................... 20

Figure 4. Interfacial polarization resistances of recently developed cathodes.............. 21

Figure 5. SEM photograph of an electrolyte-supported fuel cell................................ 21

Figure 6. Cell voltages and power densities for FC-1 to FC4 ………………............ 22

Figure 7. Peak power densities for cells FC-1 to FC-4 ………................................. 23

Figure 8. Open circuit voltages of cells FC-1 to FC-4 …….................................. 23

Figure 9. SEM micrographs of fuel cells after testing ................................................. 24

Figure 10. Mass spectrum of reformed propane on catalyst Pt-GDC............................. 25

Figure 11. Raman spectra of Pt-GDC catalyst after testing........................................... 26

Figure 12. Cell performances under pre-reformed propane............................................. 26

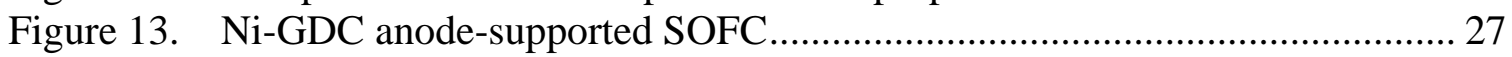

Figure 14. A schematic of Combustion CVD System .................................................... 27

Figure 15. SEM micrographs showing varied microstructures ...................................... 28

Figure 16. A columnar structure of porous SSC-SDC composite electrode................... 28

Figure 17. Unique honeycomb structure of SSC-SDC composite electrode .................. 29

Figure 18. Cross-sectional views of an SOFC cathode fabricated using CCVD............ 29

Figure 19. Schematic diagram of pd-FTIRES .............................................................. 30

Figure 20. Comparison of pd-FTIRES spectra after local baseline correction............... 32 


\section{INTRODUCTION}

Fuel cells have emerged as a leading technology to provide power sources in an efficient manner. Solid oxide fuel cells, in particular, have the potential to be among the cleanest, most efficient, and versatile technologies for energy conversion. When cleaned coal gas is used as the fuel, it can convert more than 55\% of the energy in its fuel source directly to electricity. It is possible to reach $85 \%$ overall energy efficiencies when the highquality waste heat from the electrochemical processes is recovered. SOFC emits no pollutants and as much as 65\% less carbon dioxide (a greenhouse gas) than a conventional coal-burning plant. ${ }^{[1]}$

It is the interfacial resistances that limit the performance of SOFCs at temperatures below $550^{\circ} \mathrm{C}$. With continuous progress in fabrication of thin-film electrolyte membranes, ${ }^{[2]}$ the performance of a new generation of solid-state fuel cells, the target system for SECA, will be determined essentially by the properties of the interfaces. To achieve the goals of the Vision 21 coal-based power plants or to enhance the performance of SOFC at low temperatures, the interfacial resistance of SOFCs must be dramatically reduced.

The objective of this project is to develop novel electrode materials for SOFCs to be operated at low temperatures in order to significantly reduce the cost of SOFC technology. More specifically, the technical objectives include

- To characterize the microscopic features of composite mixed-conducting electrodes and correlate with the ionic, electronic, and ambipolar transport properties as well as with the catalytic activities for pertinent electrochemical reactions;

- To gain a profound understanding of the principles of composite mixed-conducting electrodes, including simultaneous transport of ionic and electronic defects in the solid mixed conductor (influenced primarily by the defect structure), gas transport through the pores of the mixed conductor (influenced mainly by the pore structure), and the reaction kinetics at the mixed conductor/gas interface (influenced mostly by the surface structures and catalytic properties);

- To minimize interfacial polarization resistances through processing modifications, microstructure improvements, and new materials development 


\section{EXECUTIVE SUMMARY}

We have successfully fabricated composite electrodes consisting of silver and bismuth vanadates, which exhibit remarkable catalytic activity for oxygen reduction at $500-550^{\circ} \mathrm{C}$ and greatly reduce the cathode-electrolyte (doped ceria) resistances of low temperature SOFCs, down to about $0.53 \Omega \mathrm{cm}^{2}$ at $500^{\circ} \mathrm{C}$ and $0.21 \Omega \mathrm{cm}^{2}$ at $550^{\circ} \mathrm{C}$. The observed power densities of 231, 332, and $443 \mathrm{mWcm}^{-2}$ at 500,525 and $550^{\circ} \mathrm{C}$, respectively, make it possible to operate SOFCs at temperatures about $500^{\circ} \mathrm{C}$. While the long-term stability of the cathodes is yet to be characterized, the demonstrated remarkable performances (low interfacial resistances and high power densities) at low temperatures are very encouraging, implying that a new generation of low-temperature SOFCs is hopeful. Significant reduction in operating temperature will dramatically reduce not only the cost of materials but also the cost of fabrication. It also implies greater system reliability, longer operational life, and increased potential for mobile applications. Low-temperature SOFCs have great potential to be affordable for many applications, including residential and automotive applications.

Four types of anodes have been prepared on $\mathrm{Ce}_{0.9} \mathrm{Gd}_{0.1} \mathrm{O}_{1.95}$ (GDC) electrolyte pellets with two kinds of $\mathrm{NiO}$ and GDC powders to investigate the effect of microstructure on electrochemical performance of Ni-GDC composite anodes. The anode/electrolyte interfacial polarization resistances are characterized using impedance spectroscopy under open circuit conditions. The results show that the cell performance depends strongly on the anode microstructure, which in turn is determined by the anode compositions and fabrication conditions. By carefully adjusting the anode microstructure, the GDC electrolyte/anode interfacial polarization resistances have been dramatically reduced. For example, the interfacial resistance at $600{ }^{\circ} \mathrm{C}$ was decreased from $1.61 \Omega \mathrm{cm}^{2}$ for the anodes prepared using commercially available powders to $0.06 \Omega \mathrm{cm}^{2}$ for those prepared using powders derived from a glycine-nitrate process.

Although steam reforming or partial oxidation is effective in avoiding carbon deposition of hydrocarbon fuels, it increases the operating cost and reduces the energy efficiency. Based on our previous results of low-temperature SOFC running on hydrocarbon fuels, a catalyst (1 \%wt Pt dispersed on porous Gd-doped ceria) was developed for pre-reforming of propane with relatively low steam to carbon $(\mathrm{S} / \mathrm{C})$ ratio $(\sim 0.5)$, coupled with direct utilization of the reformate in low-temperature SOFCs. Propane was converted to smaller molecules during pre-reforming, including $\mathrm{H}_{2}, \mathrm{CH}_{4}, \mathrm{CO}$, and $\mathrm{CO}_{2}$. A peak power density of $247 \mathrm{~mW} / \mathrm{cm}^{2}$ was observed when pre-reformed propane was directly fed to an SOFC operated at $600^{\circ} \mathrm{C}$. No carbon deposition was observed in the fuel cell for a continuous operation of 10 hours at $600^{\circ} \mathrm{C}$. These results imply that pre-reforming could greatly enhance the performance of low-temperature SOFCs that run on higher hydrocarbon fuels.

The ability of producing vastly different microstructures and morphologies of the very same material is critical to the fabrication of functionally graded electrodes for solid-state electrochemical devices such as SOFCs and lithium batteries. By carefully adjusting deposition parameters, we have successfully produced oxide nano-powders with the size 
of $30 \sim 200 \mathrm{~nm}$. Porous films with various microstructures and morphologies are also deposited on several substrates by systematic adjustment of the deposition parameters. Symmetrical cells were fabricated by depositing cathode materials on both sides of GDC electrolytes.

In situ potential dependent FTIR emission spectroscopy is capable of probing gas-solid interactions as electrochemical reactions take place under practical conditions for fuel cell operation, providing valuable information on surface chemistry and electrochemical processes of the cathodes without any modification. Using in situ pd-FTIRES we have found evidence for two, possibly three distinct di-oxygen species present on the electrode surface. Infrared is very sensitive to several forms of adsorbed oxygen, including peroxide ions $O_{2}^{2-}$ (800-900 $\mathrm{cm}^{-1}$ ), superoxide ions $O_{2}^{-}$(1040-1190 $\left.\mathrm{cm}^{-1}\right)$, and adsorbed $\mathrm{O}_{2}\left(1500-1700 \mathrm{~cm}^{-1}\right)$. We have successfully identified which surface oxygen species is present under a particular electrical or chemical condition and have been able to deduce the reaction mechanisms. This technique will be used to probe the gas-solid interactions at or near the TPB and on the surfaces of mixed-conducting electrodes in an effort to understand the molecular processes relevant to the intrinsic catalytic activity. Broad spectral features are assigned to the electrochemical-polarization-induced changes in the optical properties of the electrode surface layer. This, to the authors' best knowledge is the first report of infrared electro-emission. The combination of in situ potential dependent FTIR emission spectroscopy (pd-FTIRES) and impedance spectroscopy (IS) will be a very powerful tool to investigate mechanisms of oxygen reduction, allowing direct correlation between the phenomenological behavior of an electrode (as determined by IS) and its surface molecular structures (as revealed by pd-FTIRES) under the actual fuel cell operating conditions. This will provide us with information that has never before been accessible, which is invaluable to rational design of better catalysts/cathodes for oxygen reduction. Further, the theory and methodology developed for study of cathodes are also being applied to study of anodes in order to achieve rational design of contaminant-tolerant anodes for SOFCs (to avoid carbon deposition and sulfur poisoning). 


\section{EXPERIMENTAL}

Anode Materials: In a Ni-GDC composite anode, $\mathrm{Ni}$ acts as both the catalyst and electronic conducting phase, while GDC mainly acts as a matrix to support the catalyst and prohibit the metal from agglomeration under operating conditions. It is believed that ceria can also improve the anode catalytic activity, especially in SOFCs using hydrocarbon fuels ${ }^{33}$. It has been demonstrated that the length of the triple-phase boundary correlates well with the reaction rate for electrochemical oxidation of hydrogen [4]; thus, the extension of the TPB becomes a determining factor in improving anode performance. This can be achieved mainly by optimizing the microstructure of the cermet anode through the adjustment of powder morphologies and particle sizes for the precursor $\mathrm{NiO}$ and ceria, and/or developing a favorable electroding process.

Cathode Materials: Our recent exploration of new cathode materials indicates that $\mathrm{Sm}_{\mathrm{x}} \mathrm{Sr}_{1-\mathrm{x}} \mathrm{CoO}_{3}$ (SSC) is very active for oxygen reduction at low temperatures (400-600C). The resistance of an SSC-SDC interface was less than $0.07 \mathrm{Ohm}-\mathrm{cm}^{2}$ at $600^{\circ} \mathrm{C}^{[5]} \mathrm{We}$ would like to systematically investigate into the SSC family of materials, including doping of other impurities, addition of a second phase to form composites, and synthesis and processing of these materials as meso-porous coatings for surface modification. The general guidelines outlined for microstructural design of anode is also applicable to the microstructural design of cathodes.

Pre-reforming of Propane: Pre-reforming, which is often an additional process step for steam reforming, can convert heavier hydrocarbons to a mixture of smaller molecules such as $\mathrm{CH}_{4}, \mathrm{H}_{2}$, and carbon oxides at low temperatures ${ }^{[6]}$. Therefore, it is possible to reduce the steam/carbon ratio dramatically by applying a pre-reforming process, compared with a general steam reforming process. Moreover, previous results ${ }^{[7]}$ demonstrated that methane could be directly used as fuel for Ni-GDC anode-based SOFCs at low temperatures $\left(<650^{\circ} \mathrm{C}\right)$ without carbon deposition. Thus, pre-reforming could be a crucial step towards effective utilization of carbon-containing fuels in lowtemperature SOFCs. In this study, we will develop novel catalysts for pre-reforming of propane, coupled with direct utilization of the reformate in low-temperature SOFCs.

Combustion CVD: A state-of-the-art system for combustion $\mathrm{CVD}^{[8]}$ has been designed and constructed in our laboratory capable of producing nano-particles and nanostructured electrodes or interfaces of various materials. To date, nanostructured powders and coatings of many catalytically active materials have been successfully produced using the CCVD system. It is found that particle size and porosity can be readily controlled by adjusting deposition parameters, such as flame temperature, substrate temperature, fuel flow rate, and solution concentration. Our initial study focused on direct deposition of nanostructured electrodes for solid oxide fuel cells. Both cathode and anode were deposited by combustion CVD on a dense electrolyte. Further, combustion CVD is ideally suited for preparation of nano-sized powers for electrochemical and catalytic applications. 


\section{RESULTS AND DISCUSSION}

Composite cathodes consisting of $\mathrm{Ag}$ and $\mathrm{Bi}_{2} \mathrm{~V}_{0.9} \mathrm{Cu}_{0.1} \mathrm{O}_{5.35}$ (BICUVOX.10) were prepared and characterized in a low-temperature SOFC based on a GDC $\left(\mathrm{Gd}_{0.1} \mathrm{Ce}_{0.9} \mathrm{O}_{1.95}\right)$ electrolyte. The cells were fabricated by a dry-pressing process and sintered at $1350^{\circ} \mathrm{C}$ for 5 hours, ${ }^{[9]}$ resulting in a dense GDC film (about $30 \mu \mathrm{m}$ thick) on an GDC/NiO substrate. Shown in Figure 1 are the cathode-electrolyte interfacial resistances as a function of cell operating temperature, together with the total cell resistances and the electrolyte resistances. The interfacial resistance between the Ag-BICUVOX cathode and the GDC electrolyte at $500^{\circ} \mathrm{C}$ is only about $0.53 \Omega \mathrm{cm}^{2}$, much smaller than those of the LSCF-GDC $\left(\sim 10 \Omega \mathrm{cm}^{2}\right)^{[10]}$, SSC-SDC $\left(\sim 1 \Omega \mathrm{cm}^{2}\right)$, or SSC/GDC $\left(\sim 1 \Omega \mathrm{cm}^{2}\right)^{[11]}$ cathode. The interfacial resistance of the Ag-BICUVOX cathode may be further reduced since the electrochemical performance of a composite cathode can be significantly improved by optimizing their microstructures and composition ${ }^{[12,13]}$ Shown in Figure 2 are the currentvoltage characteristics and the corresponding power densities for a fuel cell using the AgBICUVOX cathode. Each datum point was recorded about 30 min after the cell reached a steady state. Maximum power densities were 130, 231, and $443 \mathrm{~mW} / \mathrm{cm}^{2}$ at 450,500 , and $550^{\circ} \mathrm{C}$, respectively. The observed current and power densities at temperatures around $500^{\circ} \mathrm{C}$ represent the highest performances ever reported in the literature for SOFCs operated at these temperatures.

Electrodes for honeycomb cells based on YSZ have also been developed. The cathode is a composite consisting of silver and yttria doped bismuth oxide (YDB), which is an excellent oxygen ion conductor. YDB was synthesized using a co-precipitation method. Silver oxide was then mixed with YDB by ball milling with organic binders and acetone to form slurry, which was subsequently coated onto the inner channels of YSZ honeycombs. The coated layers were then dried, fired, and characterized in air using impedance spectroscopy. Shown in Figure 3 are several impedance spectra of a Ag-YDB composite electrode measured in gases containing different partial pressure of oxygen at $600^{\circ} \mathrm{C}$. Shown in Figure 4 are the interfacial polarization resistances of several cathodes (as determined from the impedance spectra) including a Ag-YDB composite, a recently developed functionally graded cathode ${ }^{[14]}$ and a composite consisting of lanthanum strontium manganite (LSM) and gadolinium doped ceria (GDC). ${ }^{[15,16]}$ Clearly, the polarization resistances of the Ag-YDB composite cathode are far smaller than those of other cathodes.

Ni-GDC anodes were fabricated on GDC electrolyte supported fuel cells (FC-1 to FC-4, Table 1). Shown in Figure 5 is the typical cross-sectional view of a single fuel cell. All of the single cells were made from the same batch of electrolyte discs with thickness of $\sim 210 \mu \mathrm{m}$. The cathodes were similarly all derived from the same batch of paste (SSC/GDC $=70: 30$ in weight) and were fabricated by a screen-printing process with a final firing temperature of $1000{ }^{\circ} \mathrm{C}$ for 2 hours. The only difference in the test fuel cells was the anode precursor powders and corresponding microstructure. The four test cells are named for their anode powder derivations, namely C-C, G-C, C-G, and G-G for the $\mathrm{NiO}$ and GDC powders respectively from either commercial sources (C) or GNP preparation (G). 
Shown in Figure 6 (a-d) are the cell voltage and power density as a function of current density for the different anode-based fuel cells. When applying GNP-NiO and GNP-GDC composite as anode (FC-4), the fuel cell demonstrates very high performances, as shown in Figure 6 (d). For example, the open circuit voltages (OCVs) are 0.93 and $0.84 \mathrm{~V}$, while the maximum power densities are 220 and $402 \mathrm{~mW} / \mathrm{cm}^{2}$ at 600 and $700{ }^{\circ} \mathrm{C}$, respectively. When reducing the operation temperature to $500{ }^{\circ} \mathrm{C}$, the OCV increases to $1.00 \mathrm{~V}$, closer to the theoretical electromotive force, $1.14 \mathrm{~V}\left(3 \mathrm{vol} . \% \mathrm{H}_{2} \mathrm{O}-\mathrm{H}_{2}\right.$ and air fed as the fuel and the oxidant gas). As expected, the internal electrical shorting caused by partial electronic conduction in GDC becomes less severe for thicker GDC electrolyte at lower temperatures.

Further, it can be seen from Figure 6 that the performance of these fuel cells depends strongly on the anode when keeping other conditions identical. The peak power density and open circuit voltage vs temperature for FC- 1 to FC-4 are summarized in Figures 7 and 8 for comparison. FC-4 with a G-G anode, i.e., both NiO and GDC in the anode are synthesized by glycine-nitrate process, has the highest power density among the four fuel cells tested. FC-3 with a $\mathrm{C}-\mathrm{G}$ anode, where the NiO precursor is a commercial product and GDC is synthesized by GNP, has the lowest power output. The power densities of FC-3 are only about $1 / 5$ of those of FC-4 cell over the temperature range studied. In the meantime, FC-1 and FC-2 cells with anode components of $\mathrm{C}-\mathrm{C}$ and $\mathrm{G}-\mathrm{C}$ have similar peak power densities but only about one-half of those of the FC-4 cell. The open circuit voltages of FC-1 to FC-4 reveal a similar trend. FC-4 has the highest OCVs while the FC-3 cell has the lowest values in the temperature range studied. For example, the OCVs are 0.84 and $0.77 \mathrm{~V}$ for FC-4 and FC-3 at $700{ }^{\circ} \mathrm{C}$, respectively. The OCV depends on the interfacial polarization resistances for cells based on electrolyte of mixed conduction such as ceria-based electrolytes ${ }^{[17,18]}$. Thus, different OCV values are closely correlated to different power densities, which are determined by the various anode configurations and anode/electrolyte interfacial polarization resistances.

Shown in Figure 9 are the cross-sectional views of the electrolyte and the anode after fuel cell performance testing. The relative density of the GDC electrolyte is about $95 \%$. Both $\mathrm{NiO}$ and GDC grains coarsened during firing. As can be seen from Figures 9(b) and (d), the porous anodes for FC-2 and FC-4 have similar morphologies since they all contain the same glycine-nitrate derived $\mathrm{NiO}$. The anode of cell FC-4 has a smaller average grain size and a more homogenous microstructure than FC-2. On the other hand, FC-1 and FC3, fabricated from coarser $\mathrm{NiO}$ precursor powder, have substantially different morphologies. Though some larger $\mathrm{Ni}$ grains are visible in the $\mathrm{FC}-1 \mathrm{C}-\mathrm{C}$ anode (see Figure 9(a)), the two phases (Ni and GDC) are uniformly distributed and well connected, which is desirable for anodic reactions and electronic conduction. For the anode of FC-3, it is seen that the finer GNP-derived powders tend to aggregate more easily, forming islands of isolated GDC grains. In forming these islands, the fine particles shrank substantially to leave larger pores in the anode as seen in Figure 9(c). Accordingly, these GDC “islands” and larger pores resulted in poor Ni distribution. 
It is known that fine grain size, large surface area, adequate porosity, and sufficient nickel content in the anode are essential to achieve high performance. For a Ni-GDC anode, the distribution and contact area between $\mathrm{Ni}$ and GDC particles are also of great importance. The nickel grains in a Ni-GDC cermet are regarded as the active sites for $\mathrm{H}_{2}$ oxidation, while the GDC grains act as a mechanical support for nickel and the supplier of oxygen ions in addition to their partial role in hydrogen oxidation. Ideally, the two phases of nickel and GDC should be intimately mixed to increase the triple phase boundary length. Further, the composite anode should be sufficiently porous to allow rapid gas transport. The microstructure of the anode in FC-4 satisfies all the requirements for high performance. In contrast, the larger $\mathrm{Ni}$ and GDC grains and the poor distribution observed in the FC-3 anode are responsible for the high anode/electrolyte interfacial resistance, resulting in much lower fuel cell performance compared with cell FC-4. It is also found that the anodes of FC-3 always had poor adhesion with the electrolyte layer after cell testing. When the cell was removed from the testing apparatus, the FC-3 anodes were easily peeled off or even delaminated from the electrolyte layer. In contrast, this has never occurred on the other fuel cells tested.

Pre-reforming of propane was investigated using a composite of gadolinium dopedceria and $1 \%$ wt Pt as the catalyst. The catalyst has good porous microstructure with an average particle size of about $0.2 \mu \mathrm{m}$ and BET surface area of $5 \mathrm{~m}^{2} / \mathrm{g}$. After the running of pre-reforming, there were no observable changes in morphology from the as-prepared sample. Shown in Figure 10(a) are the mass spectra of the outlet gas when $\mathrm{C}_{3} \mathrm{H}_{8}$ and steam (at $\mathrm{S} / \mathrm{C}=0.5$ ), diluted by argon were fed to the catalyst bed with $1 \%$ wt Pt-GDC as the catalyst at $650^{\circ} \mathrm{C}$ for pre-reforming. In order to examine the background of the prereforming process due to thermal cracking, the same inlet gas stream was also fed to the alumina tube without catalyst. The corresponding mass spectra were shown in Figure 10(b). It can be clearly seen that only a small amount of propane was converted to smaller molecules (e.g., $\mathrm{H}_{2}, \mathrm{CH}_{4}$ and $\mathrm{CO}$ ) in the blank runs. In contrast, when 1 \%wt PtGDC was used as the catalyst at $650^{\circ} \mathrm{C}$, nearly all propane was converted to $\mathrm{H}_{2}, \mathrm{CH}_{4}$, $\mathrm{CO}$, and $\mathrm{CO}_{2}$. The composition ratios of $\mathrm{CH}_{4}, \mathrm{H}_{2}, \mathrm{CO}$, and $\mathrm{CO}_{2}$ were 2.5:1.5:1:0.25, as estimated from the mass spectra shown in Figure 10(a). It is also noted that the S/C ratio was very low ( 0.5), which shows that the pre-reforming process using $1 \% \mathrm{wt}$ Pt-GDC as the catalyst can result in energy savings. It is believed that both Pt and GDC are activated to be excellent catalysts for the pre-reforming of propane at elevated temperatures. Additionally, it is believed that the catalytic performance of platinum is enhanced by the ionic conduction of doped ceria in a humidified atmosphere. Because of the combined effect of ceria and platinum, propane dissociates on platinum and reacts with oxygen ions adsorbed on doped ceria ${ }^{[19,20]}$. After operation for $6 \mathrm{~h}$, a small amount of carbon deposition was observed only in the area close to the entrance of the gas inlet. There are no observable differences in the XRD patterns of the Pt-GDC catalyst before and after pre-reforming operation. Shown in Figure 11 are Raman spectra of the catalyst samples before and after the pre-reforming operation. While a weak and broad carbon peak is observed for the catalyst sample taken from the area where the gas (propane and steam) enter the reactor after the pre-reforming operation, there was no observable carbon peak for the catalyst taken from other parts of the reactor after the pre-reforming operation. 
Figure 12 shows the cell voltages and power densities versus current density for a typical anode-supported fuel cell (Figure 13) operated at $600^{\circ} \mathrm{C}$, with a cell configuration of NiGDC (anode)/GDC/ $\mathrm{Sm}_{0.5} \mathrm{Sr}_{0.5} \mathrm{CoO}_{3}$-GDC (cathode). While the cathode was exposed to stationary air, the anode was fed with different fuels: hydrogen $\left(10 \mathrm{ml} / \mathrm{min} \mathrm{H}_{2}+10\right.$ $\mathrm{ml} / \mathrm{min} \mathrm{Ar}$ ), propane ( $5 \mathrm{ml} / \mathrm{min} \mathrm{C}_{3} \mathrm{H}_{8}+20 \mathrm{ml} / \mathrm{min} \mathrm{Ar}$ ), and pre-reformed propane. Each datum point was recorded about $30 \mathrm{~min}$ after the cell reached the steady state. As shown in Figure 12, open-circuit voltages (OCVs) of 0.855, 0.849, and $0.836 \mathrm{~V}$ were observed at $600^{\circ} \mathrm{C}$ for $\mathrm{H}_{2}$, pre-reformed gas, and propane, respectively. The lower OCV values compared to Nernst potentials were due to the partial electronic conduction of GDC electrolyte, which became more severe when thin electrolyte membrane was used ${ }^{[17]}$. In this study, the thickness of the electrolyte was about $20 \mu \mathrm{m}$. The maximum power densities were 258, 247, and $205 \mathrm{~mW} / \mathrm{cm}^{2}$ for the cell using three kinds of fuels, respectively. These results show that when the pre-reformed gas was used directly as fuel, the fuel cell performances were similar to those using hydrogen as fuel. Moreover, no carbon deposit was observed after continuous operation for more than $10 \mathrm{~h}$ using the pre-reformed propane as the fuel, which was consistent with our previous result when methane was fed directly as fuel to the fuel cells ${ }^{[7]}$. In contrast, when propane was directly used as the fuel, the fuel cell performance was relatively low and degraded quickly due to carbon deposition. For example, the peak power density reduced to only $140 \mathrm{~mW} / \mathrm{cm}^{2}$ after running on propane for $10 \mathrm{~h}$, while the values for fuel cells running on diluted $\mathrm{H}_{2}$ and pre-reformed propane remained stable during the 10 hours operation.

Combustion chemical vapor deposition (Combustion CVD) is an economical approach to producing a wide range of thin films. In this process, a flammable solution containing precursor materials is atomized and sprayed through a specially designed nozzle together with fuel gas and then ignited to form a combustion flame. Chemical reactions to create the desired phases are accomplished within this high temperature flame. Thin films are formed when the flame is directed onto a substrate. This technique bears both economic and technical advantages over its counterparts. First, the process is performed in openatmosphere, offering great flexibility of operation. The simple set-up and low initial capital investment are also attractive to many users. Technically, the deposition temperature can be adjusted in a very wide window, from less than $100^{\circ} \mathrm{C}$ to higher than $1500^{\circ} \mathrm{C}$. Further, this technique is cable of depositing films with thickness between 10 $\mathrm{nm}$ and $30 \mu \mathrm{m}$ at relatively high deposition rates.

Of importance to new research, is the flexibility of the Combustion CVD process. The process allows the deposition of composites, either from a single solution or through the use of multiple nozzles. In addition, since the precursors are supplied as dissolved metal ions, chemistry changes are achieved easily, allowing quick adjustment of dopants and stoichiometry of the final particles or films. Similarly, variations in structure and composition can be tailored through the thickness of the deposited films.

Schematically shown in Figure 14 is a state-of-the-art system for Combustion CVD, constructed in our laboratory, capable of producing nano-particles and nano-structured electrodes of various materials. The nanomizer (from Microcoating Technologies Inc.) is the key component of the system in creating nano-structured powders and films. To date, 
nano-structured powders and coatings of many catalytically active materials have been successfully produced using the Combustion CVD system.

Three types of porous electrodes for SOFCs are presented in this study. Shown in Figure 15(a) are cross-sectional and top view of a porous SSC+SDC film prepared by combustion CVD. The microstructure is similar to that prepared by conventional slurry coating or screen printing techniques where pores were formed uniformly between particles. In Figure 15(b), cross section and top view of a columnar structure of SSC+SDC film deposited on a YSZ substrate is seen. The existence of larger vertical channels between columns would allow easier gas diffusion to the reaction interface. The columns themselves are composed of nano-particles, creating a highly active surface area for electrochemical reactions. The thickness of the porous electrode is about 30 to 40 $\mu \mathrm{m}$, suitable for fuel cell application.

Shown in Figure 16 are some columnar structures with larger diffusion channels, which were prepared from the same solutions used for the SSC+SDC composite electrodes as those shown in Figure 15. More interestingly, with the same film material (SSC+SDC) was further fabricated in a radically different microstructure, a honeycomb structure as shown in Figure 17, with proper adjustment of deposition parameters.

We also make some interesting results on the development of cathode with nanostructure. Highly porous, excellently bonded and nano-structured electrodes for lowtemperature SOFCs have been successfully fabricated using combustion CVD approach, as shown in Figure 18. These CCVD derived electrodes consisting of nano-grains less than $50 \mathrm{~nm}$ exhibit extremely high surface area and remarkable catalytic activities.

\section{Potential dependent Fourier transform infrared emission spectroscopy (pd-}

FTIRES) has been used for the first time to study, in situ, oxygen reduction under practical operating conditions of intermediate-temperature solid oxide fuel cells (SOFCs). Figure 19 shows a schematic diagram of the optical configuration used for the emission measurements. The spectroelectrochemical cell was placed on the top of the sample cup in a Praying Mantis ${ }^{\mathrm{TM}}$ diffuse reflectance sampling accessory equipped with a high temperature reaction chamber. The Praying Mantis attachment was positioned at an emission port on the Bruker Equinox 55 FTIR spectrometer. The top surface of the electrode $\left(0.13 \mathrm{~cm}^{2}\right)$ then becomes the source of infrared light modulated by the interferometer. While the transfer optics are not perfectly optimized, the electrode surface is at the focal point of the ellipsoidal optics in the diffuse reflectance attachment and the $f$ number for the focusing mirror in the emission port is small, therefore light levels reaching the detector are high enough for high quality spectra. ${ }^{\text {[21] }}$ The electrochemical cells investigated in this study were based on samaria-doped ceria (SDC) electrolyte and samarium strontium cobalt (SSC) oxide electrodes. Symmetric cells (SSC/SDC/SSC) were used for simplicity, the cathode acting as the IR emitter and the oxygen-generating anode serving as the counter electrode. Surface emission difference spectra of functioning cathodes at $550^{\circ} \mathrm{C}$ under a variety of feed gas conditions and overpotentials were obtained. Shown in Figure 20 are the pd-FTIRES spectra recorded for a symmetric cell, SSC/SDC/SSC, in air, $1 \%$ oxygen, and in $\mathrm{N}_{2}$ for 
various applied potentials. The local baselines have been corrected with cubic polynomial fits between 1435 and $830 \mathrm{~cm}^{-1}$. This was done to separate out the electroemission effect from the adsorbate mode changes. As a comparison of the three stack plots indicates, changes in partial pressure of oxygen and the cathodic overpotential induced remarkable spectral changes. The pd-FTIRES spectra obtained at $550^{\circ} \mathrm{C}$ under cathodically polarized conditions showed a very strong absorption band at about 1124 $\mathrm{cm}^{-1}$ and two weak absorption bands at $1236 \mathrm{~cm}^{-1}$ and $930 \mathrm{~cm}^{-1}$ (near the highfrequency tail and low frequently tail of the $1124 \mathrm{~cm}^{-1}$ band), respectively. The strong band at $1124 \mathrm{~cm}^{-1}$ and the weak band around $1236 \mathrm{~cm}^{-1}$ are assigned to normal and perturbed superoxide ions $\left(O_{2}^{-}\right)$, respectively. ${ }^{[22]}$ The weak band around $930 \mathrm{~cm}^{-1}$ is assigned to peroxide ions $\left(\mathrm{O}_{2}^{2-}\right)$, again based on analogous assignments in the literature. The interactions between superoxide ions and the electrode surface, as revealed by in situ pd-FTIRES, are very sensitive to the local oxygen concentration. The interfacial structural data were also correlated to AC impedance and chronoamperometric measurements. In addition to the bands associated with adsorbed superoxide ions, broad spectral features assigned to the electrochemical polarization were also observed. These spectral features are believed to be due to polarizationinduced changes in the optical properties of the electrode itself. 


\section{CONCLUSIONS}

Composites electrodes consisting of silver and bismuth vanadates exhibit remarkable catalytic activity for oxygen reduction at $500-550^{\circ} \mathrm{C}$ and greatly reduce the cathodeelectrolyte (doped ceria) resistances of low temperature SOFCs, down to about 0.53 $\Omega \mathrm{cm}^{2}$ at $500^{\circ} \mathrm{C}$ and $0.21 \Omega \mathrm{cm}^{2}$ at $550^{\circ} \mathrm{C}$. The observed power densities of 231, 332, and $443 \mathrm{mWcm}^{-2}$ at 500,525 and $550^{\circ} \mathrm{C}$, respectively, make it possible to operate SOFCs at temperatures about $500^{\circ} \mathrm{C}$. While the long-term stability of the cathodes is yet to be characterized, the demonstrated remarkable performances (low interfacial resistances and high power densities) at low temperatures are very encouraging, implying that a new generation of low-temperature SOFCs is hopeful. Significant reduction in operating temperature will dramatically reduce not only the cost of materials but also the cost of fabrication. It also implies greater system reliability, longer operational life, and increased potential for mobile applications. Low-temperature SOFCs have great potential to be affordable for many applications, including residential and automotive applications.

GDC electrolyte-supported fuel cells were fabricated and tested at intermediate temperatures. Impedance spectra showed that the resistances of anode/electrolyte interfaces depend strongly on the anode microstructure, which in turn was essentially determined by the compositions and fabrication conditions. Anodes consisting of finer precursor powders of $\mathrm{NiO}$ and GDC exhibit excellent performances. The anode/electrolyte interfacial resistances are about 0.06 and $0.05 \Omega \mathrm{cm}^{2}$, translating to maximum power densities of 220 and $402 \mathrm{~mW} / \mathrm{cm}^{2}$ at 600 and $700^{\circ} \mathrm{C}$, respectively, for a fuel cell based on a $210 \mu \mathrm{m}$ thick GDC electrolyte. Further, substantial decrease in performance was observed when the firing temperature of the anodes was increased from 1250 to $1350^{\circ} \mathrm{C}$.

Lowering the operation temperature and effectively utilizing practical fuels are two critical issues facing the development of economically competitive solid oxide fuel cell (SOFC) systems. Although steam reforming or partial oxidation is effective in avoiding carbon deposition of hydrocarbon fuels, it increases the operating cost and reduces the energy efficiency. A catalyst (1\%wt Pt dispersed on porous Gd-doped ceria) was developed for pre-reforming of propane with relatively low steam to carbon (S/C) ratio $(\sim 0.5)$, coupled with direct utilization of the reformate in low-temperature SOFCs. Propane was converted to smaller molecules during pre-reforming, including $\mathrm{H}_{2}, \mathrm{CH}_{4}$, $\mathrm{CO}$, and $\mathrm{CO}_{2}$. A peak power density of $247 \mathrm{~mW} / \mathrm{cm}^{2}$ was observed when pre-reformed propane was directly fed to an SOFC operated at $600^{\circ} \mathrm{C}$. No carbon deposition was observed in the fuel cell for a continuous operation of 10 hours at $600^{\circ} \mathrm{C}$. These results imply that pre-reforming could greatly enhance the performance of low-temperature SOFCs that run on higher hydrocarbon fuels.

The ability of producing vastly different microstructures and morphologies of the very same material is critical to the fabrication of functionally graded electrodes for solid-state electrochemical devices such as SOFCs and lithium batteries. By carefully adjusting deposition parameters, we have successfully produced oxide nano-powders with the size of $30 \sim 200 \mathrm{~nm}$. Porous films with various microstructures and morphologies are also 
deposited on several substrates by systematic adjustment of the deposition parameters. Nano-structured electrodes fabricated by combustion CVD show extremely high surface area and remarkable catalytic activities.

In situ potential dependent FTIR emission spectroscopy is capable of probing gas-solid interactions as electrochemical reactions take place under practical conditions for fuel cell operation, providing valuable information on surface chemistry and electrochemical processes of the cathodes without any modification. Using in situ pd-FTIRES we have found evidence for two, possibly three distinct di-oxygen species present on the electrode surface. Broad spectral features are assigned to the electrochemical-polarization-induced changes in the optical properties of the electrode surface layer. This, to the authors' best knowledge is the first report of infrared electro-emission. 


\section{Tables and Figures}

Table 1. Sources of precursor powders and firing temperature of the anode samples (65 wt.\% $\mathrm{NiO}$ and 35 wt.\% GDC).

\begin{tabular}{c|c|c|c}
\hline Fuel cell & Anode component & $\begin{array}{c}\text { Firing } \\
\text { temperature }\end{array}$ & $\begin{array}{c}\text { Anode } \\
\text { abbreviation }\end{array}$ \\
\hline FC-1 & Comm-NiO Comm-GDC & & C-C \\
FC-2 & GNP-NiO Comm-GDC & \multirow{2}{*}{$1250{ }^{\circ} \mathrm{C}$} & G-C \\
FC-3 & Comm-NiO GNP-GDC & & C-G \\
FC-4 & GNP-NiO GNP-GDC & & G-G \\
\hline FC-12 & Comm-NiO Comm-GDC & \multirow{2}{*}{$1350{ }^{\circ} \mathrm{C}$} & C-C \\
FC-42 & GNP-NiO GNP-GDC & & G-G \\
\hline
\end{tabular}

Figures

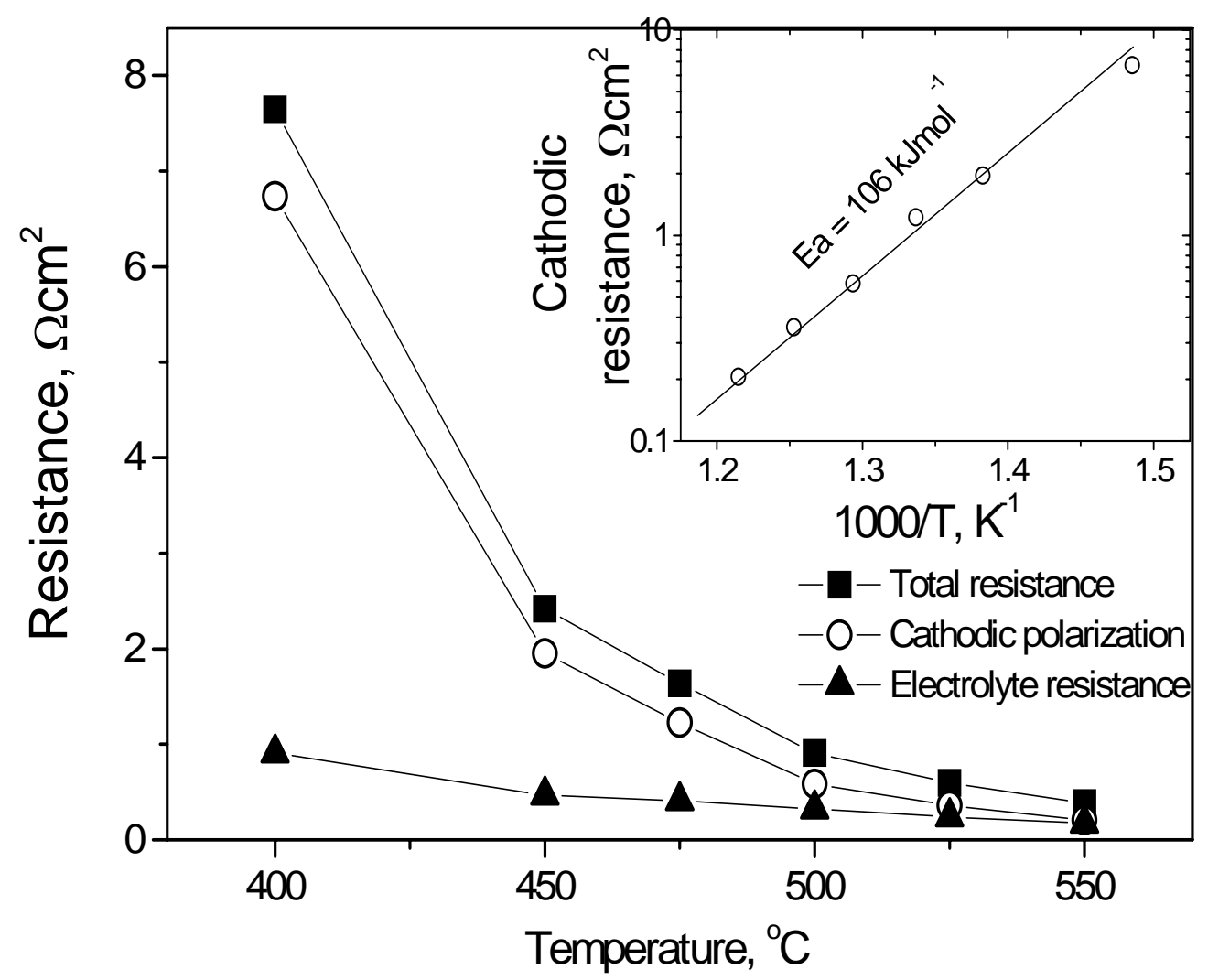

Figure 1. Total cell resistances, cathode-electrolyte interfacial resistances, and electrolyte resistances as determined from impedance spectra. 


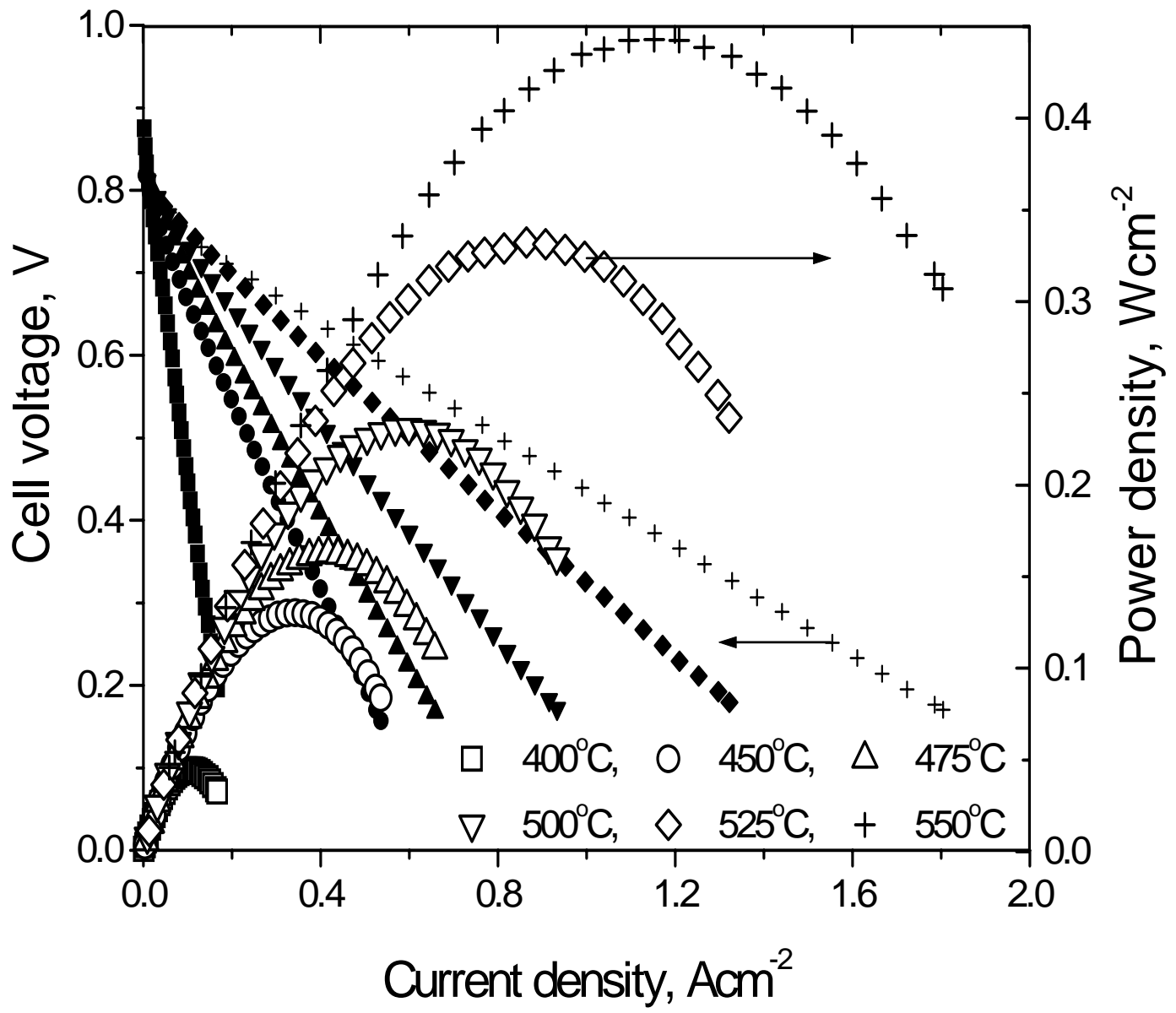

Figure 2. Cell voltages and power densities as a function of current densities for a fuel cell consisting of a Ag-BICUVOX composite cathode, a GDC electrolyte, and a Ni-GDC composite anode. 

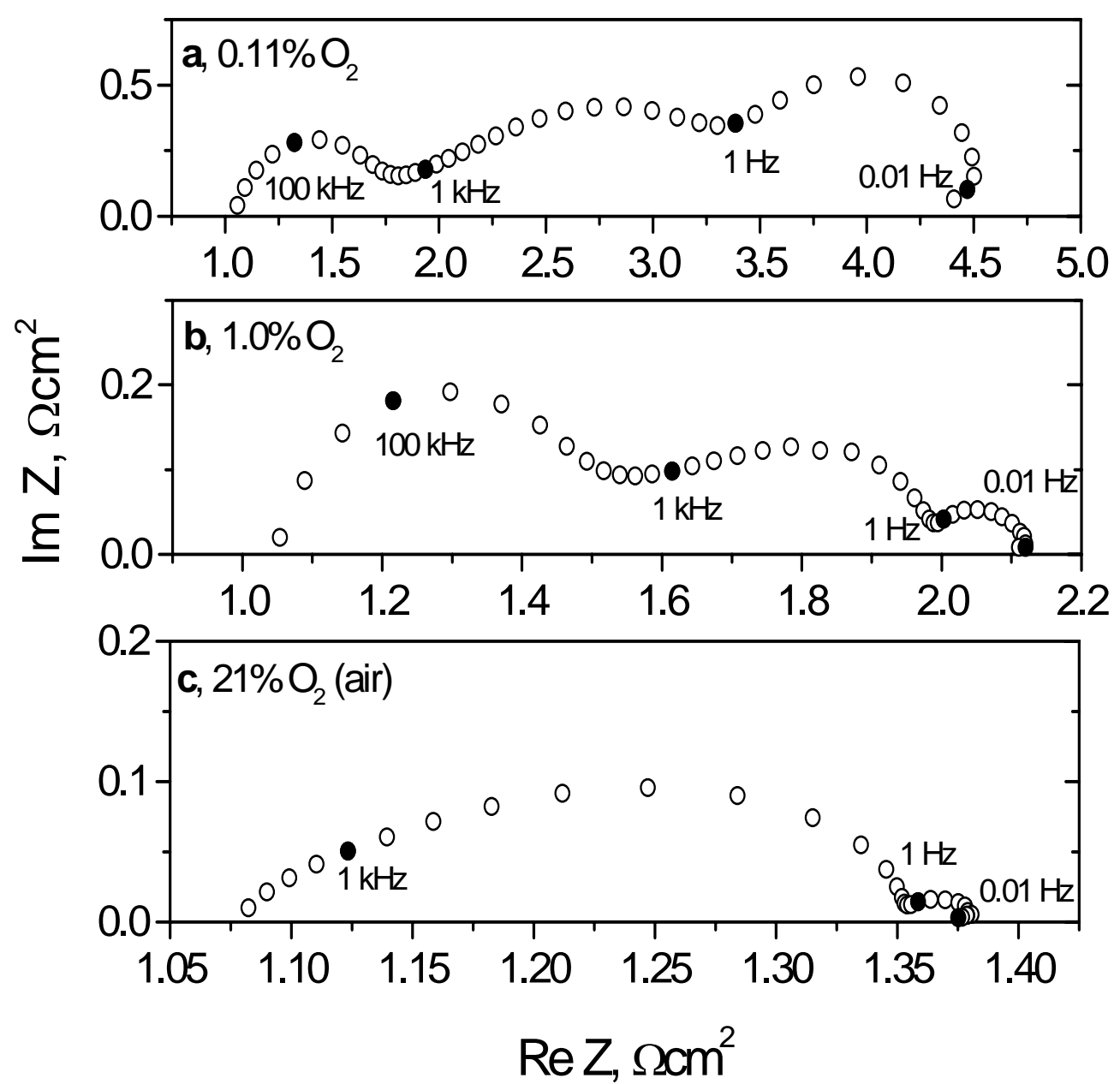

Figure 3. Impedance spectra of an YDB composite cathode measured at $600^{\circ} \mathrm{C}$ in gases containing different partial pressure of oxygen. 


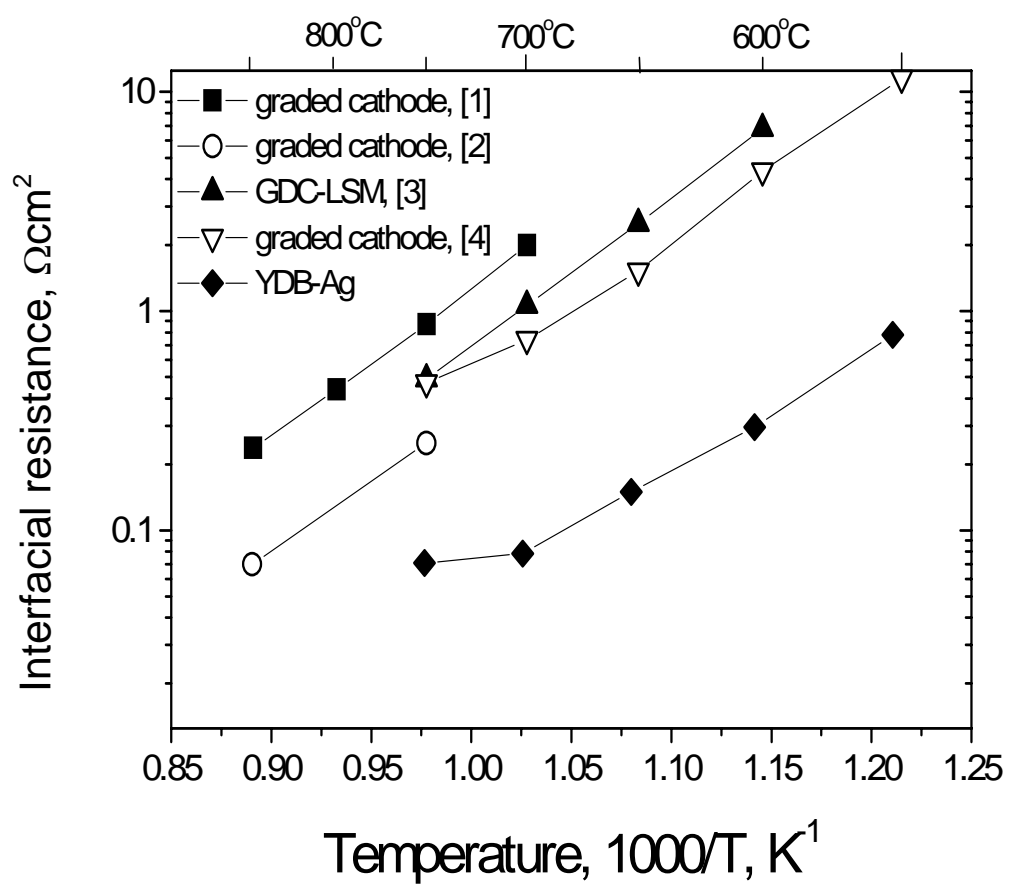

Figure 4. Interfacial polarization resistances of recently developed cathodes: Ag-YDB, a functional graded cathode, and an LSM-GDC composite.

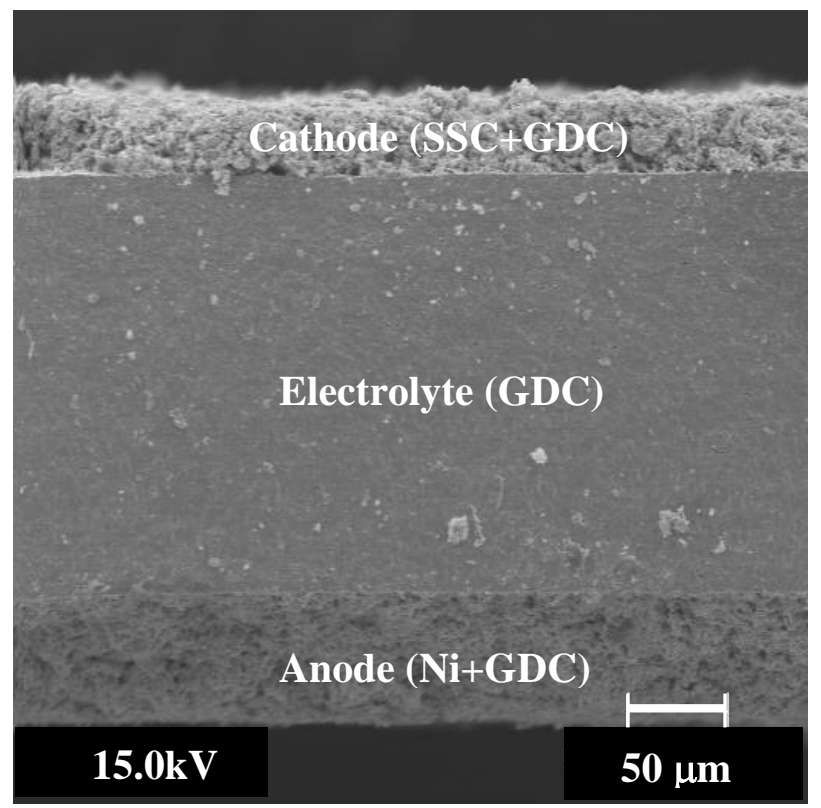

Figure 5. A cross-sectional view (SEM photograph) of a typical electrolyte-supported fuel cell showing 3-layered structure after cell performance measurement. 

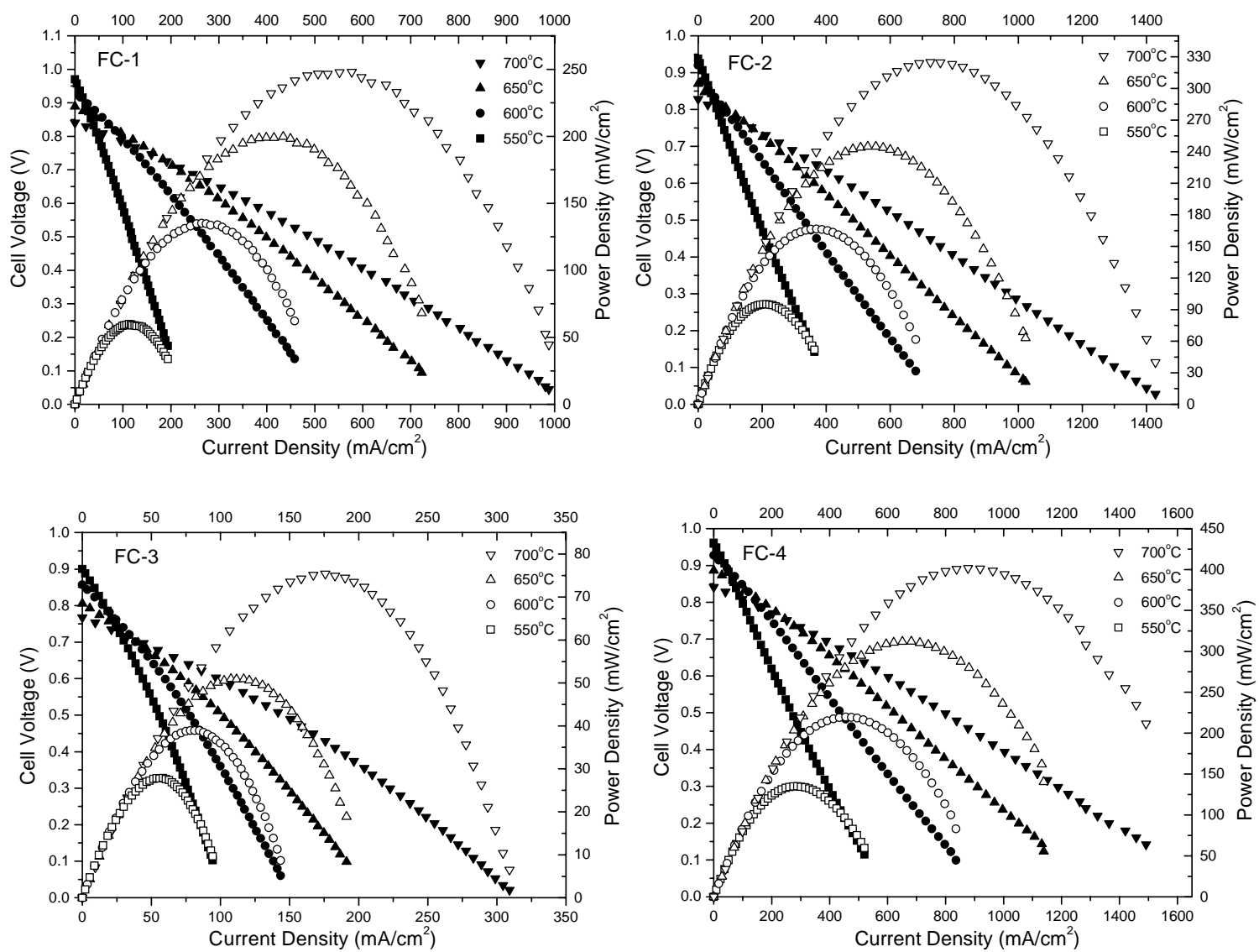

Figure 6. Cell voltages and power densities as a function of operating current density for fuel cells based on different anodes (FC-1 to FC-4 as described in Table 1). 


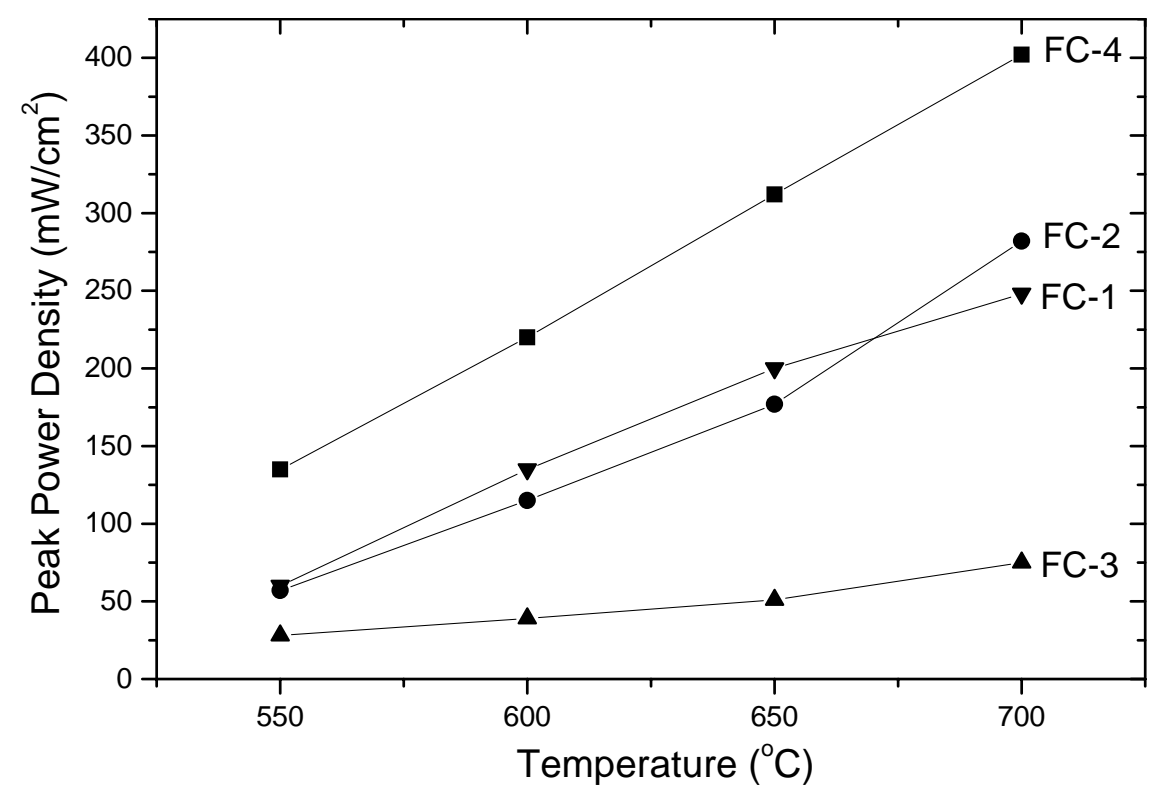

Figure 7. The peak power densities at different operating temperatures for cells FC-1 to FC-4.

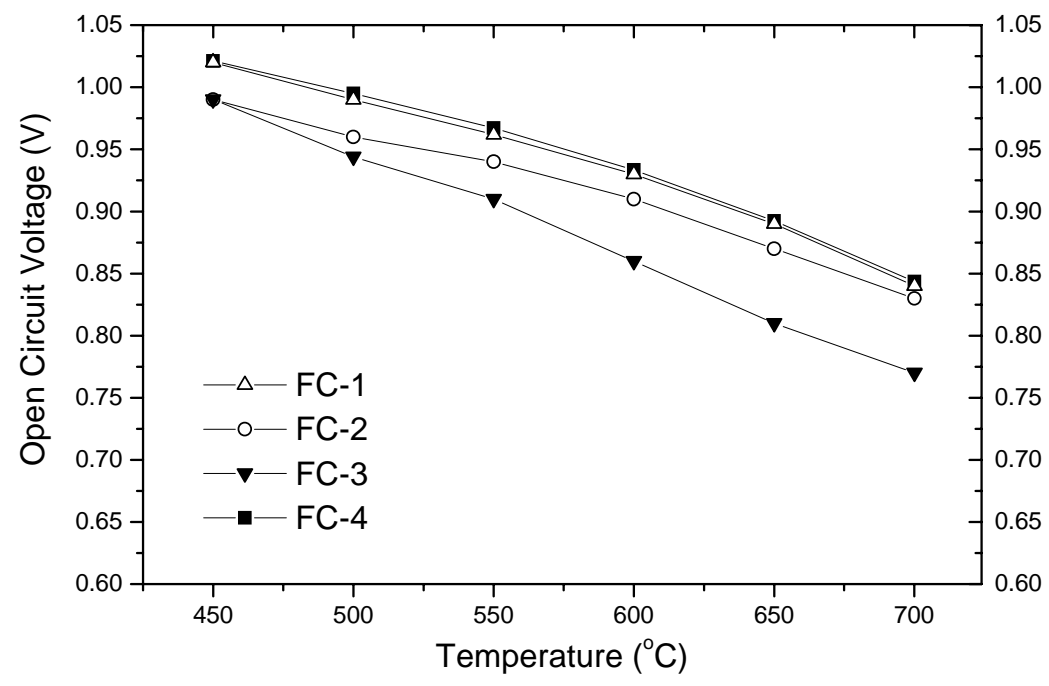

Figure 8. Open circuit voltages of the four cells (FC-1 to FC-4) measured at different temperatures. 

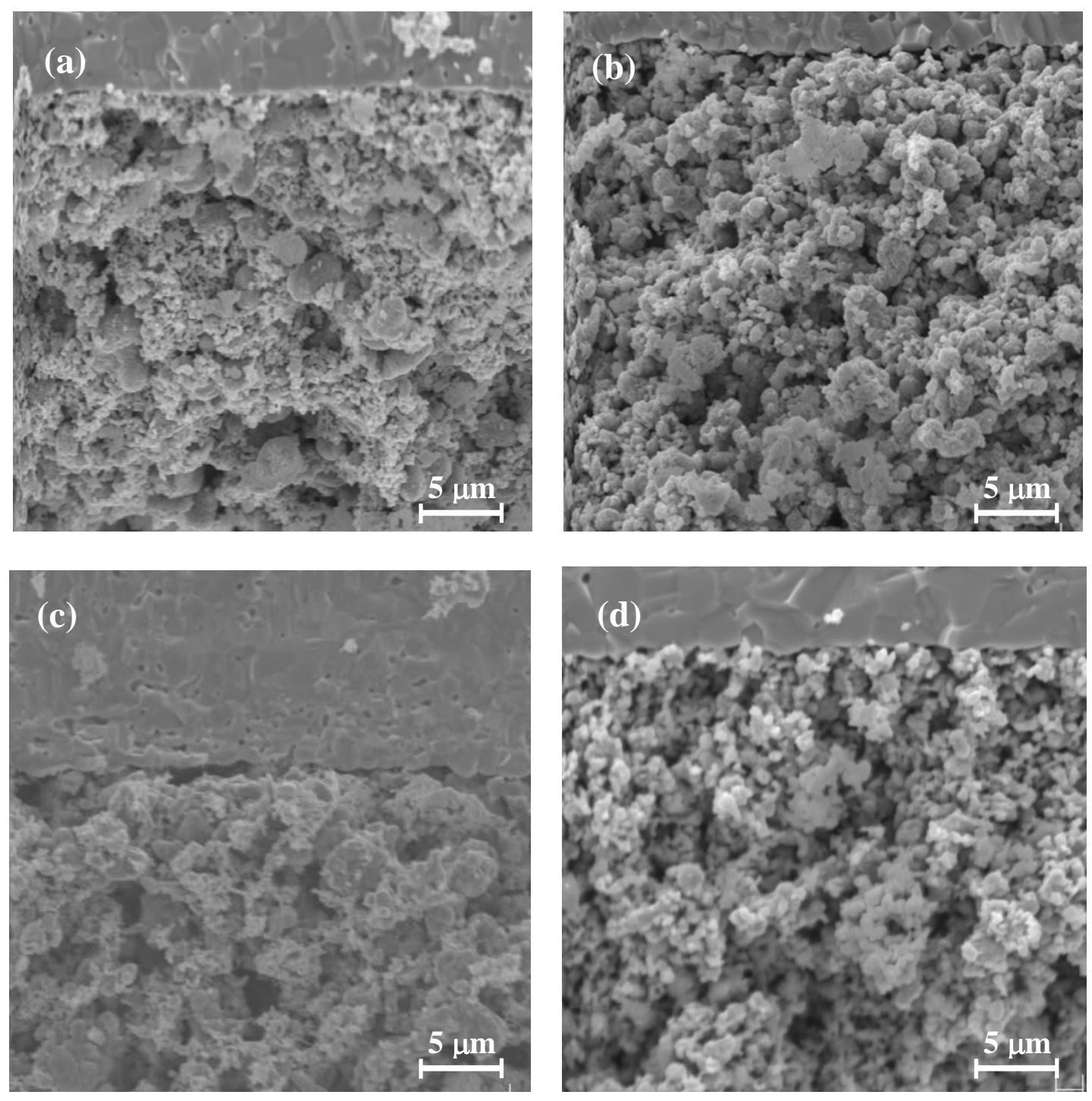

Figure 9. Cross-sectional views (SEM micrographs) of electrolyte and anode components after fuel cell performance testing. The precursor powders for the anodes were (a) commercial $\mathrm{NiO}$ and commercial GDC, (b) GNP NiO and commercial GDC, (c) commercial NiO and GNP GDC, and (d) GNP NiO and GNP GDC, respectively. 

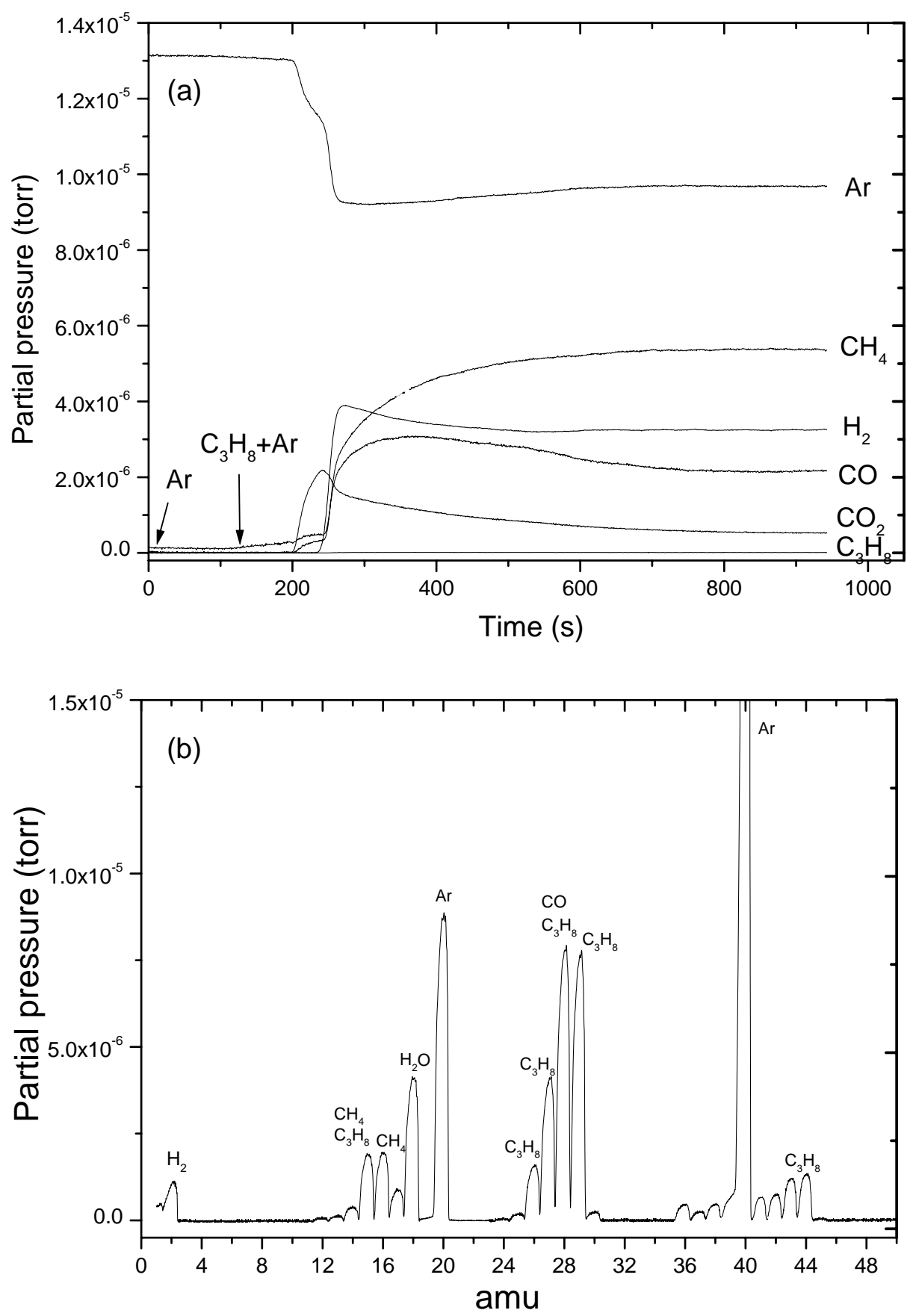

Figure 10. (a) A typical mass spectrum of the reformed propane on catalyst Pt-GDC at $650^{\circ} \mathrm{C}(\mathrm{S} / \mathrm{C}=0.5)$, and (b) mass spectrum of the outlet gas of propane and steam flowing through a heated alumina tube $\left(650^{\circ} \mathrm{C}\right)$ without catalyst. 


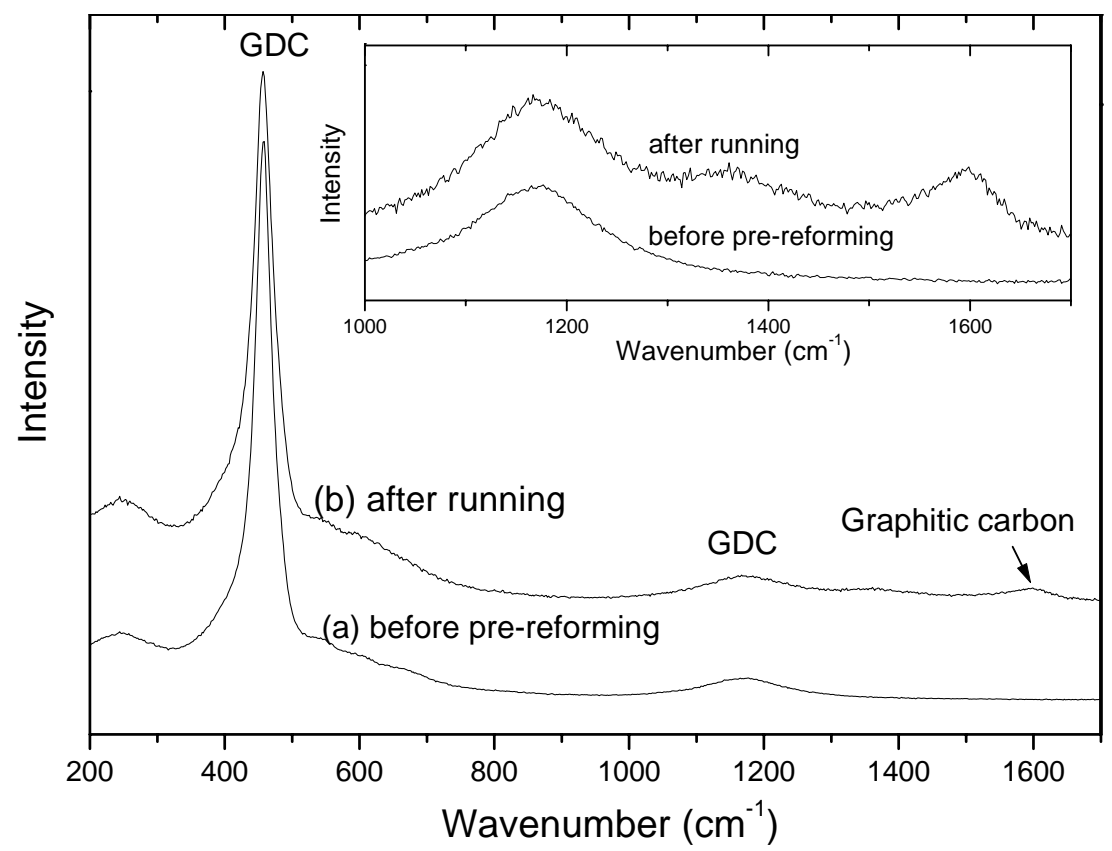

Figure 11. Room temperature Raman spectra of Pt-GDC catalyst (a) before prereforming, and (b) after pre-reforming operation (in the gas entrance area). Insert shows the intensity for wavenumber from 1000 to $1700 \mathrm{~cm}^{-1}$.

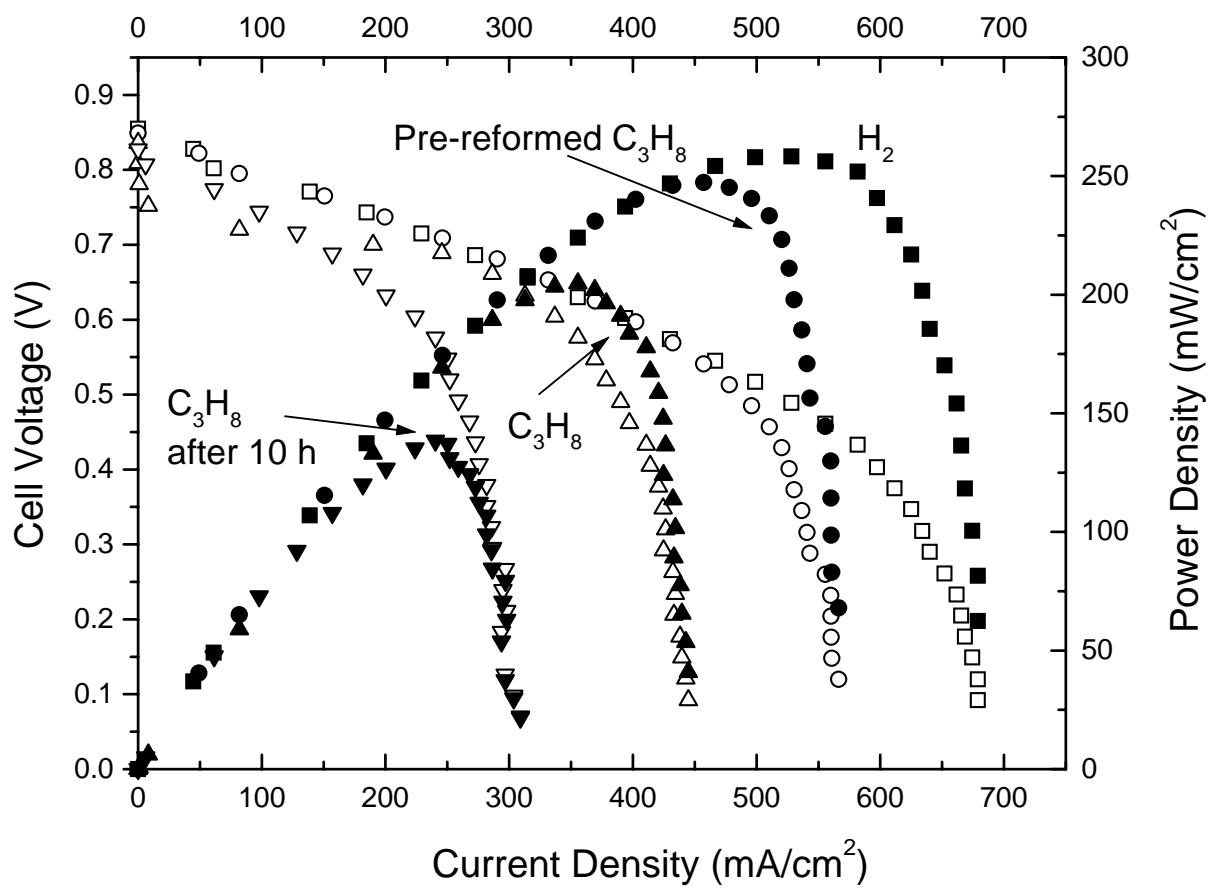

Figure 12. Cell voltages (open symbols) and power densities (solid symbols) as a function of current densities for a fuel cell, Ni-GDC (anode) /GDC/ $/ \mathrm{Sm}_{0.5} \mathrm{Sr}_{0.5} \mathrm{CoO}_{3}$-GDC (cathode), at $600^{\circ} \mathrm{C}$ (measured after operating for $0.5 \mathrm{~h}$ ). The data are shown for the following fuels: ( $\square$ ) $10 \mathrm{ml} / \mathrm{min} \mathrm{H}_{2}$ in $10 \mathrm{ml} / \mathrm{min} \mathrm{Ar}$; (o) pre-reformed propane in 20 $\mathrm{ml} / \mathrm{min}$ Ar; and $(\Delta) 5 \mathrm{ml} / \mathrm{min}$ propane in $20 \mathrm{ml} / \mathrm{min}$. 


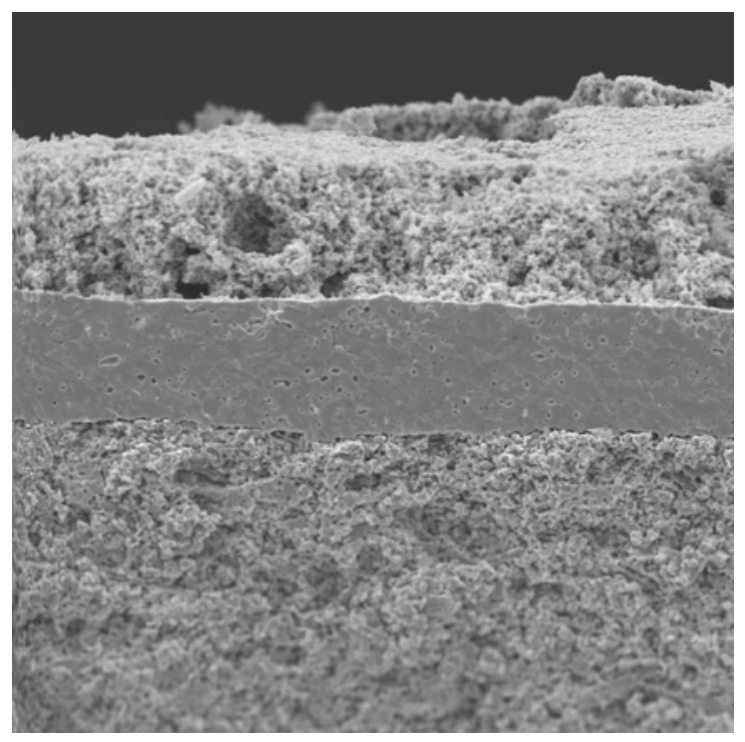

Figure 13. A cross-sectional view (SEM photograph) of a Ni-GDC anode-supported SOFC with a thin GDC electrolyte layer.

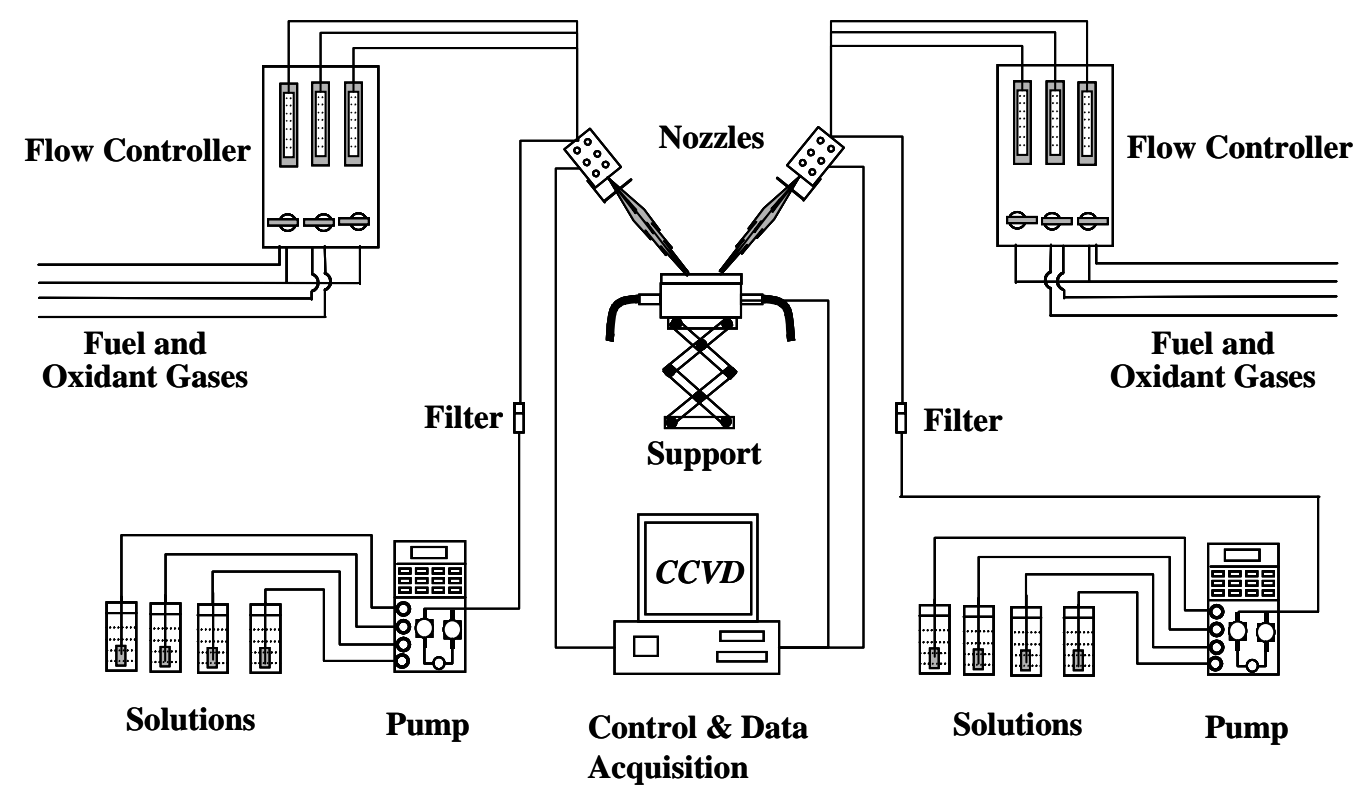

Figure 14. A schematic of Combustion CVD System. 

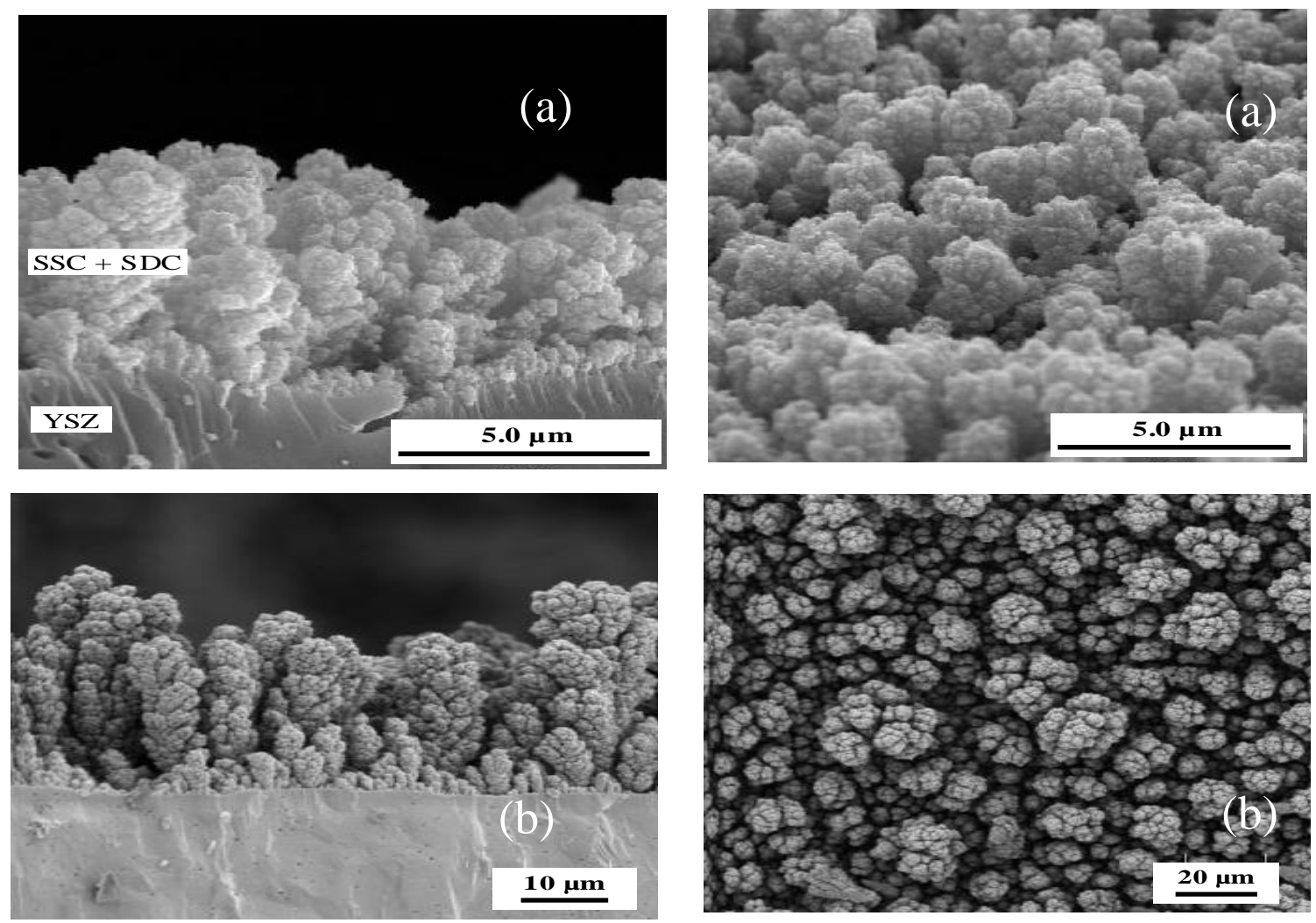

Figure 15. Varied microstructures (cross-section and surface) for the same composition: (a) a uniformly distributed microstructure and (b) a columnar structure to facilitate gas transport.
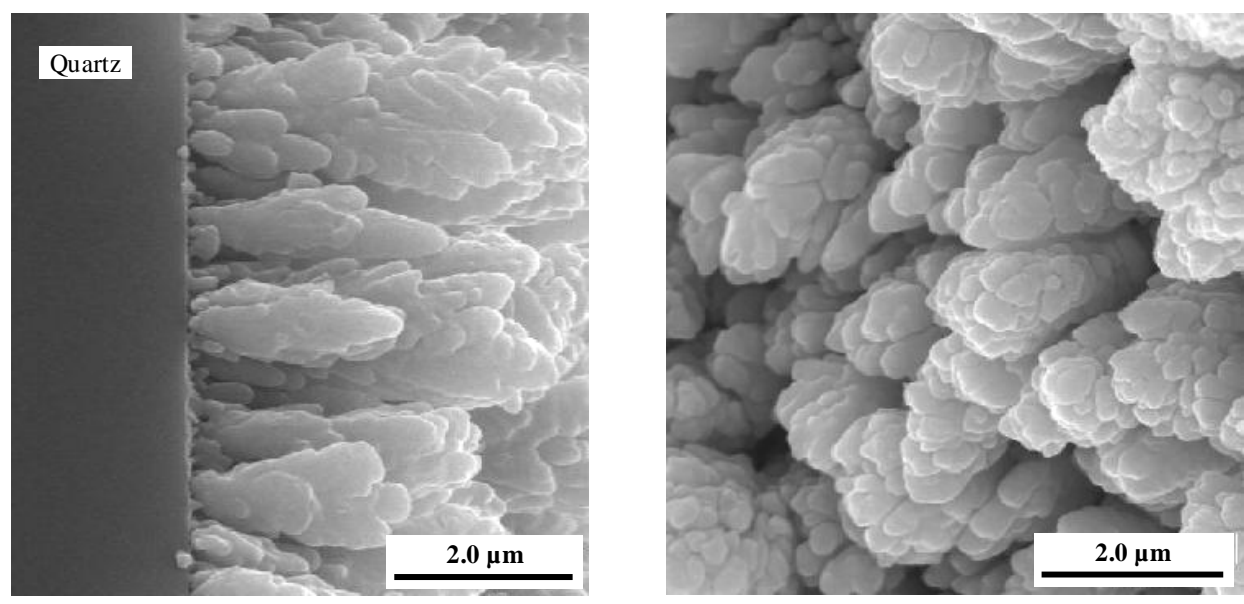

Figure 16. A more highly columnar structure of porous SSC-SDC composite electrode on a quartz substrate. 

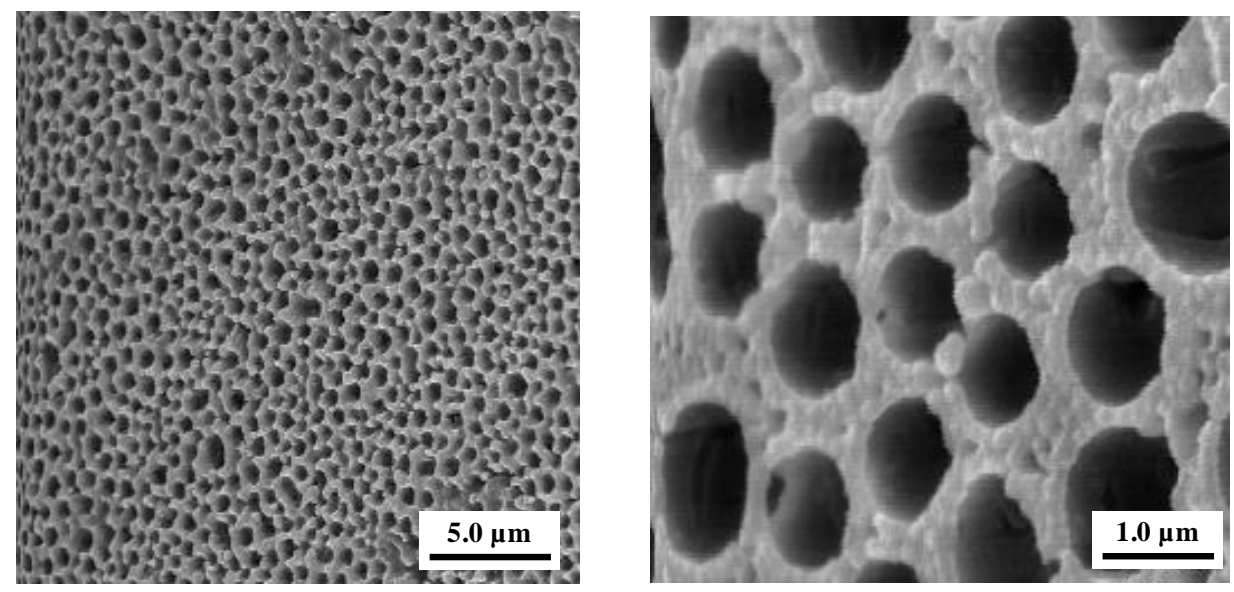

Figure 17. Unique honeycomb structure composed of SSC-SDC composite.

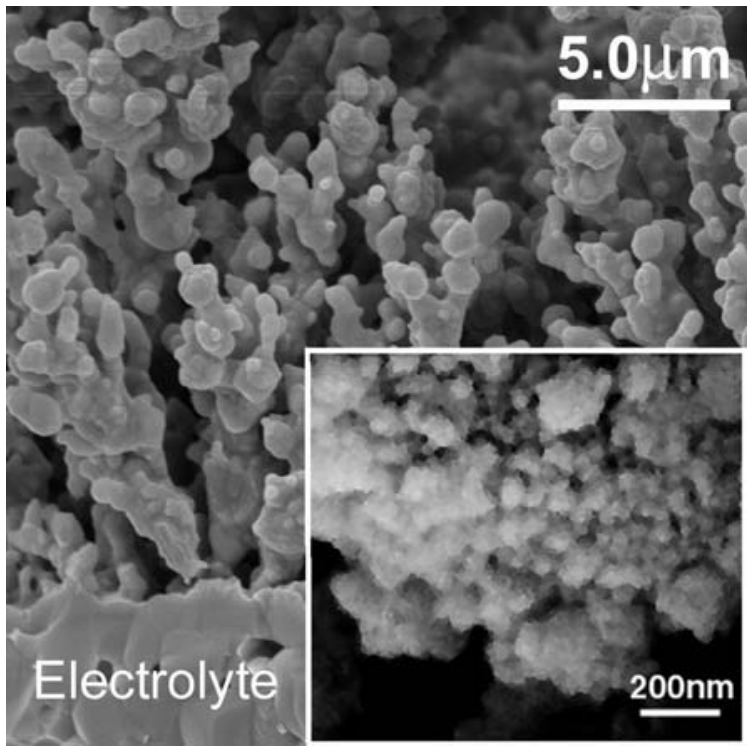

Figure 18. Cross-sectional views of an SOFC cathode fabricated using combustion CVD. 


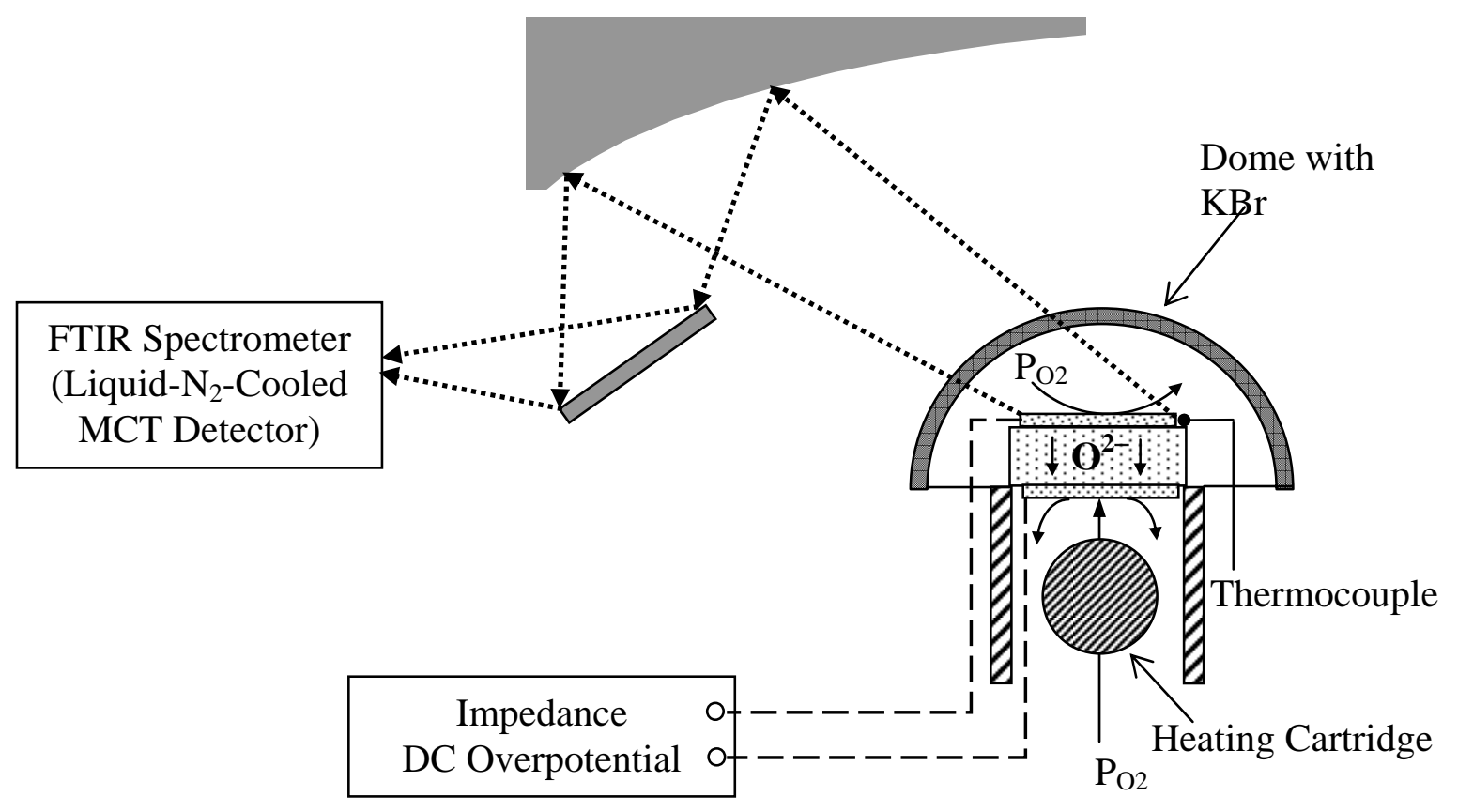

Figure 19. Schematic diagram of optical configuration for pd-FTIRES experiments. 


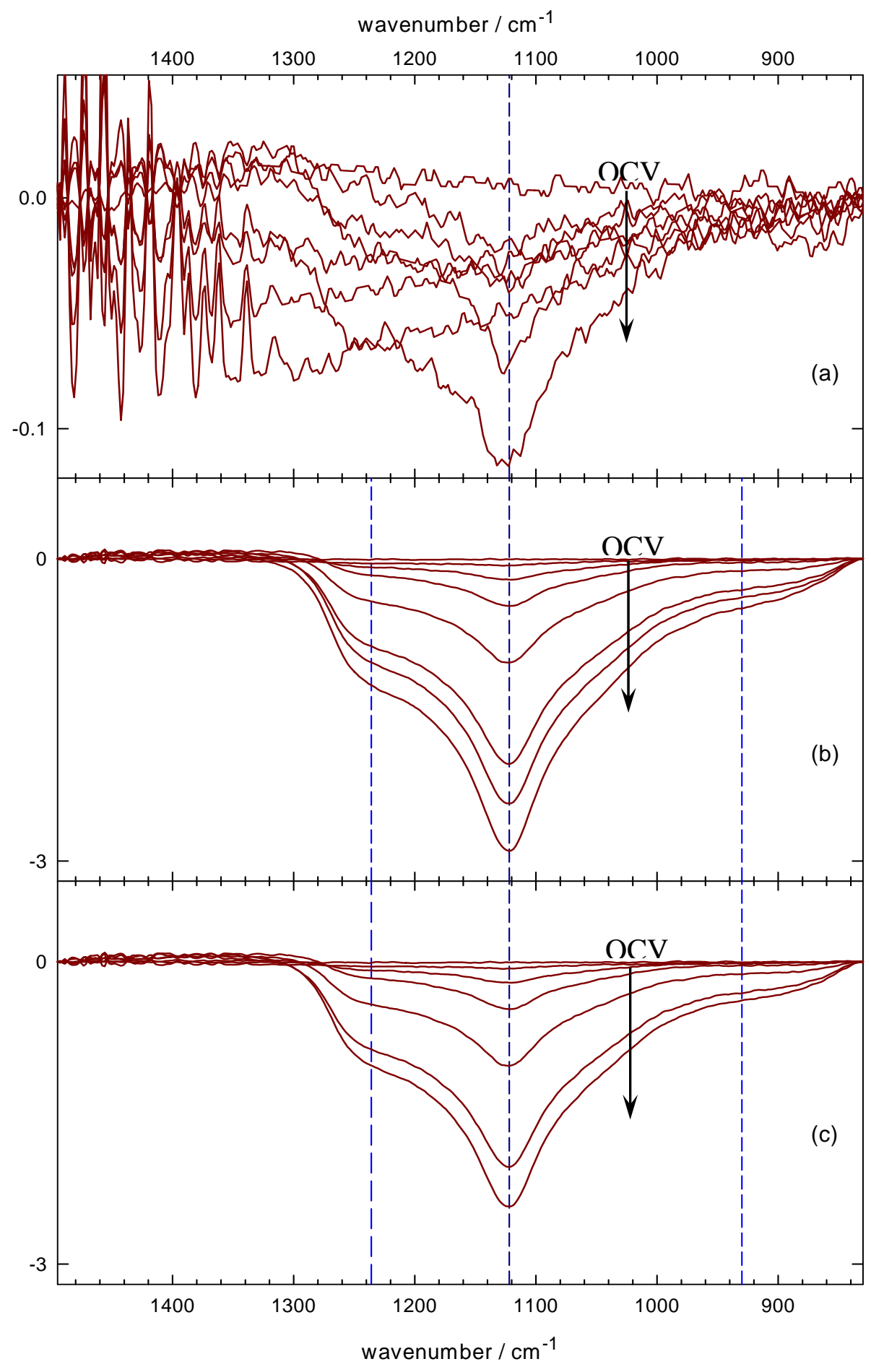

Figure 20. Comparison of pd-FTIRES spectra after local baseline correction for three different feed gas conditions: (a) air, (b) $1 \% \mathrm{O}_{2}$ in $\mathrm{N}_{2}$ and (c) $\mathrm{N}_{2}$. Cathodic overpotential excursions range from (a) 0 to $320 \mathrm{mV}$ (b) 0 to $760 \mathrm{mV}$ and (c) 0 to $690 \mathrm{mV}$. The arrows indicate the increasing direction of cathodic overpotentials. 


\section{REFERENCES}

1 Solid State Energy Conversion Alliance (SECA) Workshop Proceedings, Baltimore, Maryland, June 1-2, 2000.

2 S. de Souza, S. J. Visco, and L.C. De Jonghe, J. Electrochem. Soc. 144 (1997) L 35.

3 R.J. Gorte, S. Park, J.M. Vohs, C. Wang, Adv. Mater. 12 (2000) 1465.

4 B. de Boer, M. Gonzalez, H. J. M. Bouwmeester, H. Verweij, Solid State Ionics 127 (2000) 269.

5 C. R. Xia, F. L. Chen, M. L. Liu, Electrochem. Solid-State lett. 4 (2001) A52

6 G.A. Tompsett, C. Finnerty, K. Kendall, T. Alston, N.M. Sammes, J. Power Sources 86 (2000) 376.

7 S. Zha, A. Moore, H. Abernathy, M. Liu, J. Electrochem. Soc. 151 (2004) A1128.

8 A.T. Hunt, W.B. Carter, and J.K. Cochran, Appl. Phys. Lett. 63 (1993) 266.

C. R. Xia, M. L. Liu, J. Am. Ceram. Soc. 84 (2001) 1903

10 E. P. Murray, S.A. Barnett, Solid State Ionics 143 (2001) 265

11 C. R. Xia, M. L. Liu, Solid State Ionics 144 (2001) 249

12 B. C. H. Steele, K.M. Hori, S. Uchino, Solid State Ionics 135 (2000) 445

13 V. Dusastre, J.A. Kilner, Solid State Ionics 126 (1999) 163

${ }^{14}$ N. T. Hart, N. P. Brandon, M. J. Day, and N. Lapena-Ray, J. Power Sources 106 (2002) 42.

${ }^{15}$ P. Holtappels and C. Bagger, J. Europ. Cera. Soc. 22 (2002) 41.

${ }^{16}$ E. P. Murray, S. A. Barnett, Solid State Ionics 143 (2001) 265.

${ }^{17}$ M. Liu, "Electrode Kinetics and Transport Properties of Mixed Ionic-Electronic Conductors," in Ionic and Mixed Conducting Ceramics, T. A. Ramanarayanan and H. L. Tuller, Editors, The Electrochemical Society, Pennington, NJ, Vol. 91-12, 191-215 (1991).

${ }^{18}$ M. Liu and A. Joshi, "Characterization of Mixed Ionic Electronic Conductors," in Ionic and Mixed Conducting Ceramics, T. A. Ramanarayanan and H. L. Tuller, Editors, The Electrochemical Society, Pennington, NJ, Vol. 91-12, 95-109 (1991).

${ }^{19}$ K. Otsuka, Y. Wang, E. Sunada, I. Yamanaka, J. Catal. 175 (1998) 152.

${ }^{20}$ O.A. Marina, M. Mogensen, Appl. Catal. A 189 (1999) 117.

${ }^{21}$ M. Handke and N.J. Harrick, Appl. Spectrosc. 40 (1986) 401.

${ }^{22}$ M. Che and A. J. Tench, Characterization and Reactivity of Molecular Oxygen Species on Oxide Surfaces, in: “Advances in Catalysis”, Academic Press, New York, 1983, vol. 32, p.1. 